SŁawomir Dorocki, Marta Boguś, Monika Borowiec

Uniwersytet Pedagogiczny, Kraków, Polska

\title{
Przestrzenne zróżnicowanie rozwoju przemysłu biotechnologicznego
}

\author{
Spatial Diversity of the Biotechnological \\ Industry's Development
}

\begin{abstract}
Streszczenie: Współcześnie przemysł biotechnologiczny uznawany jest za z najważniejszych sektorów gospodarki wysokich technologii oraz stanowi istotny czynnik rozwoju społeczno-gospodarczego i procesów kształtowania gospodarki opartej na wiedzy. Charakteryzuje się on innowacyjnością i szybkim rozwojem, które są związane z zaangażowaniem wysoko wykwalifikowanej kadry specjalistów, centrów badawczych, różnorodnych źródeł informacji i inwestycji, jak również powiązań gwarantujących przepływ informacji. Przemysł ten ma wiele zastosowań w branży spożywczej, produkcji organizmów zmodyfikowanych genetycznie, w sektorze farmaceutycznym, w służbie zdrowia, w sektorze detergentów i bioremediacji, leśnictwie oraz rolnictwie.

Celem prowadzonych badań było określenie zróżnicowania procesów rozwoju przemysłu biotechnologicznego, zmiany jego potencjału oraz struktury na świecie i w Polsce. Największe znacznie w kształtowaniu tego przemysłu mają najwyżej rozwinięte państwa na świecie. Współcześnie pojawiają się także nowe centra przyspieszonego rozwoju tego przemysłu, m.in. na Litwie, w Hiszpanii, w Turcji, na Słowacji. W Polsce możliwości rozwoju przemysłu biotechnologicznego zależą w dużym stopniu od dostępności wysoko wykwalifikowanej kadry, rozwiniętego technologicznie zaplecza badawczo-rozwojowego, polityki proinnowacyjnej państwa, współpracy międzynarodowej i dostępności do kapitału.
\end{abstract}

\begin{abstract}
Today's biotechnology is widely regarded as one of the most important sectors of information technology, a new wave of a knowledge-based economy. It is characterized by innovation and a very fast pace of development, which is connected with the involvement of highly qualified specialists, research centres, varied sources of information, investments, as well as interconnections to guarantee the flow of information. Biotechnology has got a potential wide range of applications, such as the food industry, production of genetically modified organisms, pharmaceutics, healthcare, detergents and bioremediation, forestry and agriculture.

The aim of the article is to show the diversity in the development and structure of biotechnology in the world as well as in Poland. There is a huge variety in the world when it comes to the structure and space where the biotech development occurs. According to the collected data, even though the dynamic expansion of biotechnology takes place in new centers of development in Lithuania, Spain, Turkey and Slovakia, there is an obvious predominant role of highly developed countries. In Poland, biotechnology is mainly based on the potential of universities' scientific centers and metropolitan centers.
\end{abstract}


Furthermore, biotech development is determined by several factors. The distance from scientific centers, location of universities, financial sources and international cooperation must be taken into consideration. Policy of a country is also one of the major determinants.

Słowa kluczowe: biotechnologia, badania i rozwój, wysokie technologie, ośrodki naukowe, patent Key words: biotechnology, research and development, high technology, scientific centers, patent

\section{WPROWADZENIE}

Przemysł biotechnologiczny uznawany jest współcześnie za jeden z najważniejszych sektorów gospodarki wysokich technologii i stanowi on istotny czynnik rozwoju społeczno-gospodarczego i procesów kształtowania gospodarki opartej na wiedzy (Zioło 2006, 2008; Pugatch, Torstensson, Chu 2012). Zgodnie z przyjętą przez autorów definicją, biotechnologia oznacza zastosowanie procesów technologicznych, które wykorzystując organizmy żywe lub ich składniki, wytwarzają lub modyfikują produkty o określonym zastosowaniu, a zatem jest interdyscyplinarną nauką, integrującą ze sobą nauki przyrodnicze i technologiczne. Przemysł ten zajmuje się przede wszystkim: produkcją kultur starterowych w przemyśle spożywczym, produkcją organizmów zmodyfikowanych genetycznie, sektorem farmaceutycznym, sektorem detergentów i bioremediacji, biotechnologią w rolnictwie do celów niespożywczych i w leśnictwie.

Rozwój firm biotechnologicznych następuje głównie w bliskości światowej klasy uczelni wyższych, zapewniających dostęp do wysoko wykwalifikowanej siły roboczej i infrastruktury badawczej oraz wiąże się z dużym ryzykiem inwestycyjnym wynikającym z szybkich przemian technologicznych (Baum, Silverman 2004), a zatem rozwój biotechnologii związany jest z dostępem do dużych zasobów kapitałowych i polityką państwa.

W świetle przedstawionych przesłanek w niniejszym artykule podjęto problematykę rozwoju przemysłu biotechnologicznego. W badaniach zmierzano do określenia zróżnicowania procesów jego rozwoju, zmiany potencjału oraz struktury na świecie i w Polsce. Podstawę niniejszych analiz stanowiły głównie dane zaczerpnięte z komercyjnej (odpłatnej) bazy BiotechGate zawierającej dane o firmach i instytucjach biotechnologicznych i farmaceutycznych z całego świata. Dane zawarte w bazie są jedynie wartościami orientacyjnymi, ponieważ nie uwzględnia ona wszystkich podmiotów biotechnologicznych na świecie lub dane te są niepełne (np. brak jest daty powstania, liczby pracowników itp.). Jednakże po dokonaniu zestawienia wartości z bazy BiotechGate z innymi zestawieniami biotechnologicznymi, np. OECD lub krajowymi opracowaniami dotyczącymi sektora biotechnologicznego, można zauważyć, że różnice w liczebności firm w poszczególnych wykazach są niewielkie. Ponadto wykorzystano dane statystyczne zawarte w internetowych bazach: EUROSTAT, Organizacji Współpracy Gospodarczej i Rozwoju, uczelnie.pl i Głównego Urzędu Statystycznego. 
ROZMIESZCZENIE FIRM I PATENTÓW BIOTECHNOLOGICZNYCH NA ŚWIECIE

Zróżnicowanie przestrzeni światowej w zakresie liczby firm biotechnologicznych w 2011 roku jest bardzo duże (ryc. 1). Największa liczba firm znajduje się w USA, tj. 5,7 tys., co stanowi niemal 24,9\% ogólnej liczby podmiotów biotechnologicznych na świecie. Kolejne pozycje zajmują Niemcy, Wielka Brytania, Szwajcaria i Kanada skupiające zbliżoną liczbę firm. Łącznie te cztery państwa skupiają 33,5\%, a razem ze Stanami Zjednoczonymi na ich obszarze zlokalizowanych jest 13,3 tys. firm biotechnologicznych, które stanowią 58,5\% ogólnej ich liczby na świecie. Znacznie mniejsza liczba firm znajduje się we Włoszech, w Szwecji, Hiszpanii, Francji, Holandii i Indiach, gdzie udział ten waha się od 5,6\% do 3,2\% ogólnej ich liczby. Polska w tym zestawieniu plasuje się na stosunkowo wysokiej pozycji, pomiędzy Belgią i Irlandią z ok. 1\% firm biotechnologicznych na świecie. Można zatem stwierdzić, że przemysł biotechnologiczny rozwija się przede wszystkim w rozwiniętych krajach głównie Europy Zachodniej i Ameryki Północnej, natomiast nie zaznacza się na obszarze takich potentatów gospodarczych jak Chiny czy Brazylia.

Kolejnym wskaźnikiem, który obrazuje zróżnicowanie w rozmieszczeniu firm biotechnologicznych na świecie jest liczba zatrudnionych w tego typu firmach. Największy udział zatrudnionych w firmach biotechnologicznych w ogólnej ich liczbie zaznacza się w USA 36,3\%, a następnie w Niemczech, Holandii, Kanadzie i Wielkiej Brytanii (ryc. 2). Łącznie w tych czterech państwach zatrudnieni w firmach biotechnologicznych stanowią niemal 30\% ogólnej ich liczby na świecie, a razem z USA - 65,6\%. Natomiast pod względem liczby zatrudnionych w firmach biotechnologicznych w przeliczeniu na 1000 mieszkańców najwyższą pozycję zajmuje Szwajcaria (237 osób), a następnie Szwecja (122 osoby) i Dania (74 osoby). Tak wysoka pozycja Szwajcarii związana jest zarówno z jej wysokim poziomem rozwoju gospodarczego, jak również z inwestycjami zagranicznymi i polityką państwa wspierającą innowacyjne gałęzie przemysłu (Weijian, Jaeyong 1997). W Polsce wartość wskaźnika wynosi tylko 6,5 osób, jednakże należy zaznaczyć, że dane te są jedynie orientacyjne, ponieważ odnoszą się jedynie do instytucji zgłoszonych do bazy danych.

Komercjalizacja biotechnologii wymaga często długich terminów realizacji, co spowodowane jest trudnościami pozyskania kapitału na inwestycje o wysokim ryzyku, dlatego tak ważne dla rozwoju biotechnologii są regulacje prawne oraz ochrona praw własności intelektualnej w postaci patentów. Liczba patentów biotechnologicznych po okresie systematycznego wzrostu o 20,4\% w latach 1995-2000, w kolejnych latach zmniejszała się średniorocznie o 3,5\% (ryc. 3A) ${ }^{1}$. W konsekwencji zmniejszania dynamiki liczby patentów biotechnologicznych ich udział w ogólnej liczbie patentów zmniejszył się z 10,6\% w latach 90-tych do $6,7 \%$ obecnie. Wysoka dynamika zgłaszanych patentów w latach 90-tych związana była z intensyfikacją badań nad ludzkim genomem. Obecny spadek związany jest z bardziej restrykcyjnymi kryteriami patentowania wynalazków genetycznych i obniżonymi możliwościami czerpania korzyści z rozwoju biotechnologii.

\footnotetext{
http://www.oecd-ilibrary.org/sites/sti scoreboard-2009-en/02/08/index.html?contentType=\&itemId=/content/ chapter/sti_scoreboard-2009-25-en\&containerItemId=/content/serial/20725345\&accessItemIds=/content/book/sti_scoreboard-2009-en\&mimeType=text $/ \mathrm{html}$
} 

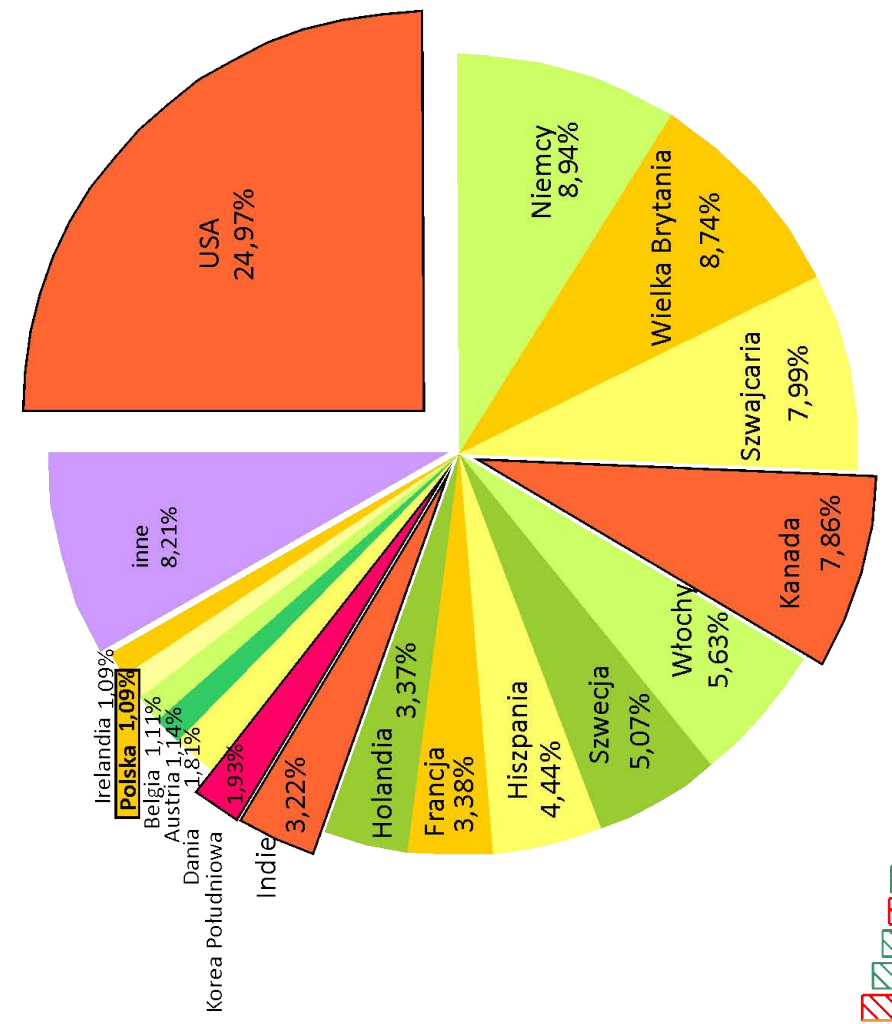

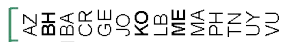

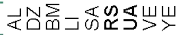
8 늘 欲识 $\underline{0}$ 던전

$\sum_{0}^{\frac{1}{0}}$

然方

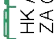

$\stackrel{x}{\geq}$

然

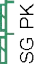

Nơ⿱

咅

을

군

舀

学

뜯

ब岜

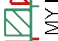

$\mathbb{N}$

四 뚠

Nit?

$\sqrt{7}$

미고

NII $=$

तIII

NII:

NIV 岗

NIII:

MIIII

111118

\$1/1/1/1/11: $\leftleftarrows$

ब1/1/1/1/

\$111/11/1/

\$1/11/1/1/1/

M1/1/1/1/1/1/1

\$1/1/1/1/1/1/1/5

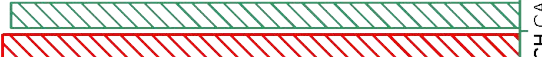

$01 / 1 / 1 / 1 / 1 / 1 / 1 / 1 / 1 / 1 / 1 / 1 / 1 / 1 \%$

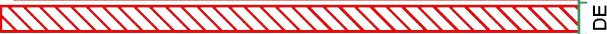

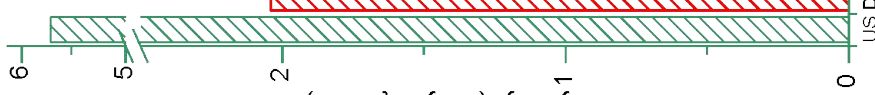

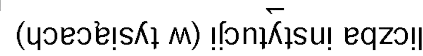




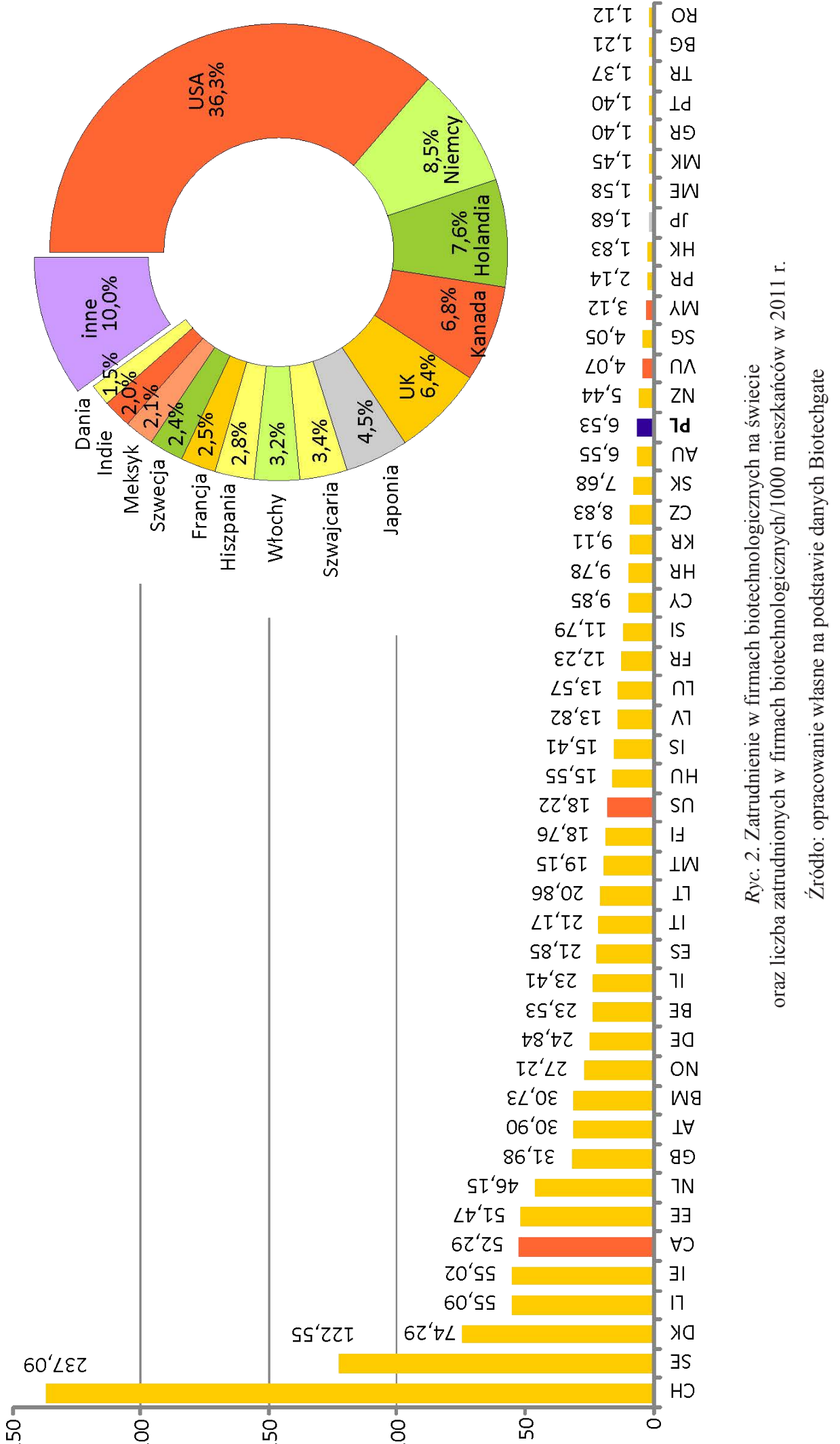




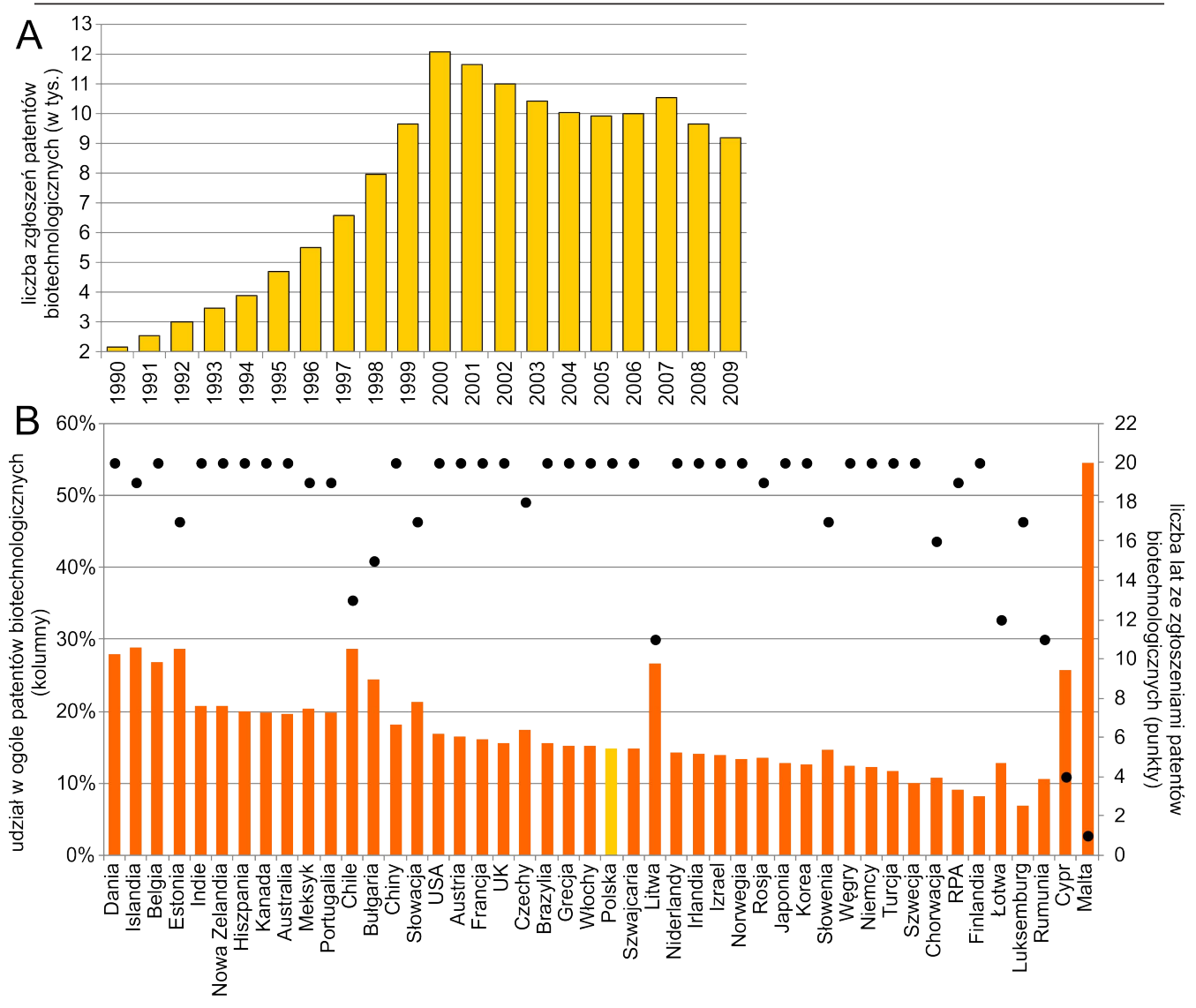

Ryc. 3. Patenty biotechnologiczne w świecie w latach 1990-2009 (A) oraz udział patentów biotechnologicznych w ogóle patentów wysokiej technologii (B)

Źródło: opracowanie własne na podstawie danych OECD

Udział patentów biotechnologicznych w ogólnej liczbie zgłaszanych patentów z zakresu wysokich technologii $\mathrm{w}$ danym kraju jest zróżnicowany. Najwyższym udziałem zgłaszanych patentów biotechnologicznych charakteryzuje się Malta $(55,1 \%)$, a także Islandia, Estonia, Belgia, Dania, Chile, Bułgaria, Litwa i Cypr, gdzie stanowi on niemal 30\% (ryc. 3B). Najmniejszym udziałem - poniżej 10\% - odznaczają się Luksemburg, Finlandia, Szwecja. Wskazywać to może na fakt, iż rozwój przemysłu biotechnologicznego ze względu na stosunkowo niską kapitałochłonność w porównaniu do innych sektorów wysokich technologii dokonuje się nie tylko w krajach wysoko rozwiniętych, ale także w krajach, które dopiero wchodzą na przyśpieszoną ścieżkę rozwoju gospodarki opartej na wiedzy i prowadzą określoną politykę w tym zakresie (Kenney, Buttel 1985). Ponadto tak wysoki udział patentów biotechnologicznych w tych rozwijających się krajach jest poniekąd wynikiem niskiej liczby ogółu patentów z sektora wysokich technologii, co jest szczególnie widoczne w przypadku Malty i Cypru. 


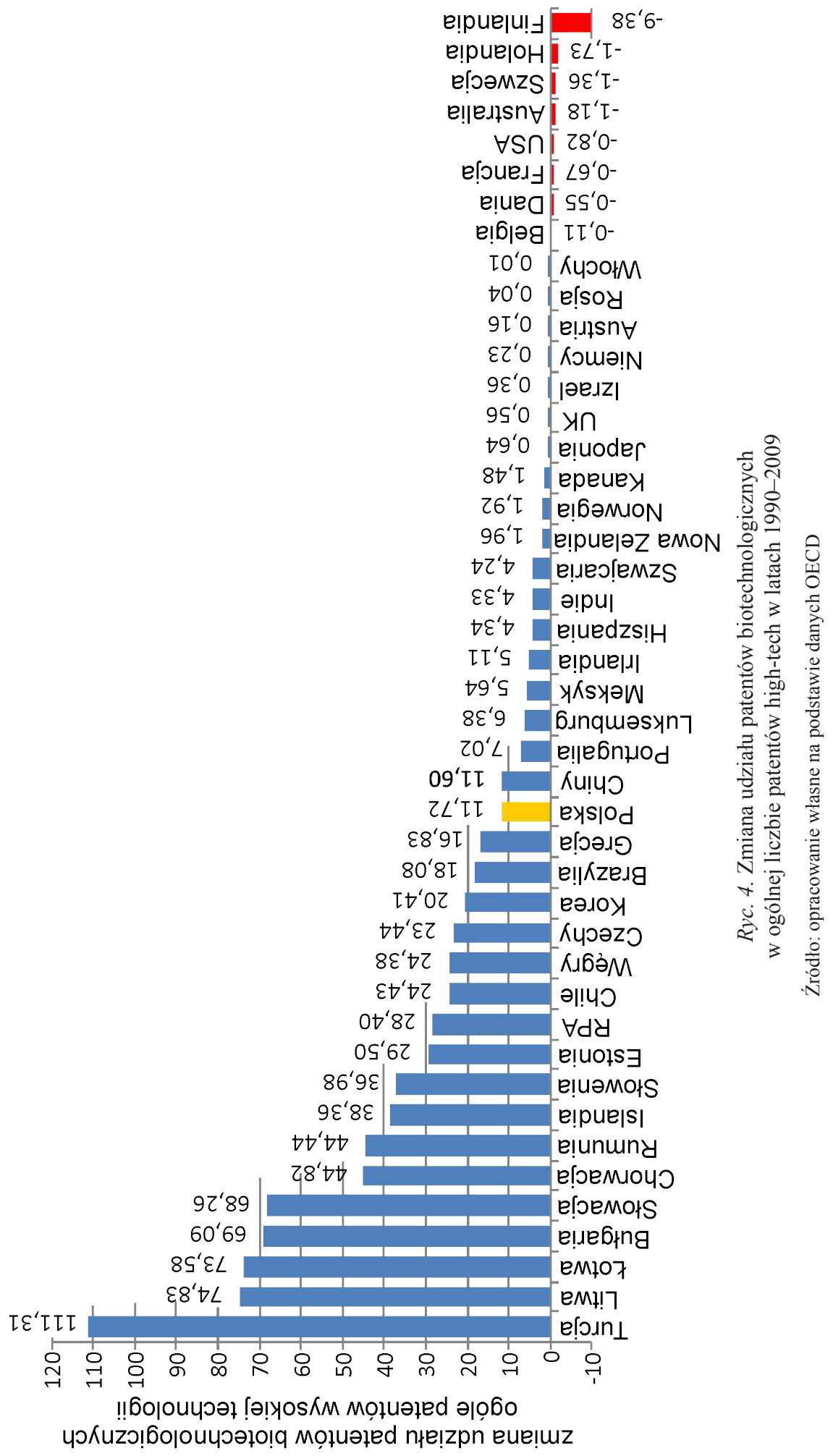


Prawidłowość tę potwierdza również zmiana udziału patentów biotechnologicznych w ogólnej liczbie patentów wysokiej technologii w latach 1990-2009. Najwyższą dynamiką wzrostu odznacza się Turcja, w której udział ten wzrósł o 111,3\%, a następnie Litwa, Łotwa, Bułgaria i Słowacja, w których wzrost udziału patentów biotechnologicznych w ogólnej liczbie patentów wahał się od 74,8\% do 68,3\% (ryc. 4). Tak wysoki wzrost patentów w Turcji jak i w pozostałych krajach Europy Wschodniej dotyczył głównie rozwoju biotechnologii w sektorze rolniczym i przemyśle spożywczym, natomiast w mniejszym stopniu w zaawansowanej biotechnologii terapeutycznej (Dobos, Karaali 2003). Natomiast spadek udziału patentów biotechnologicznych w ogólnej liczbie patentów wystąpił w Finlandii (9,4\%) oraz niewielki spadek poniżej 2\% w Holandii, Szwecji, Austrii, USA, Francji, Danii i Belgii. Spadki te w dużej mierze spowodowane są polityką delokalizacyjną wielkich korporacji biotechnologicznych i farmaceutycznych oraz polityką państw przyciągających zagraniczne inwestycje (Grebel, Krafft, Saviotti 2006; Orsenigo 2006; Kilvits, Purju 2007; Micek 2008a; Lux 2009). W Polsce w tym czasie obserwuje się nieznaczny wzrost udziału tego typu patentów i wynosił on $11,7 \%$, czyli podobnie jak w Chinach.

\section{ZRÓŻNICOWANIE STRUKTURY I ROZWOJU FIRM BIOTECHNOLOGICZNYCH NA ŚWIECIE}

Firmy biotechnologiczne charakteryzują się różnym stopniem powiązań światowych, na co wskazuje stosunek liczby zatrudnionych w firmach zlokalizowanych w danym państwie do liczby zatrudnionych w zagranicznych filiach tej firmy. Największymi powiązaniami światowymi pod tym względem charakteryzują się Słowacja i inne kraje, w których przemysł ten znajduje się w początkowej fazie rozwoju, co jest wynikiem wspomnianej powyżej polityki delokalizacyjnej międzynarodowych koncernów (Falk i in. 2002) (ryc. 5). Generalnie stwierdza się, że istnieje duża zależność pomiędzy zatrudnionymi w głównych siedzibach firm, a ich filiach za granicą. W przypadku Polski obserwuje się niski stopień powiązań światowych, co w dużej mierze jest wynikiem braku wspierania rozwoju biotechnologii przez rząd oraz liberalizacji prawodawstwa. Potwierdza to zróżnicowanie średniej liczby zatrudnionych w tego typu firmach zarówno w kraju, gdzie znajduje się siedziba firmy, jak i w jej filiach za granicą (ryc. 6). Na uwagę zasługuje fakt, że wśród firm biotechnologicznych przeważają małe i średnie firmy, podczas gdy największe pod względem zatrudnienia firmy zlokalizowane są w krajach rozwijających się, jak np. Meksyk, Bangladesz czy Iran. Może to świadczyć o międzynarodowym podziale pracy. Instytucje innowacyjne, zazwyczaj złożone z mało licznych zespołów badawczych, zlokalizowane są w wysoko rozwiniętych regionach, podczas gdy produkcja zlokalizowana jest w mniej rozwiniętych regionach świata. Proces ten zauważalny jest również w inwestycjach zagranicznych, które powielają ten mechanizm (Dorocki 2011). 


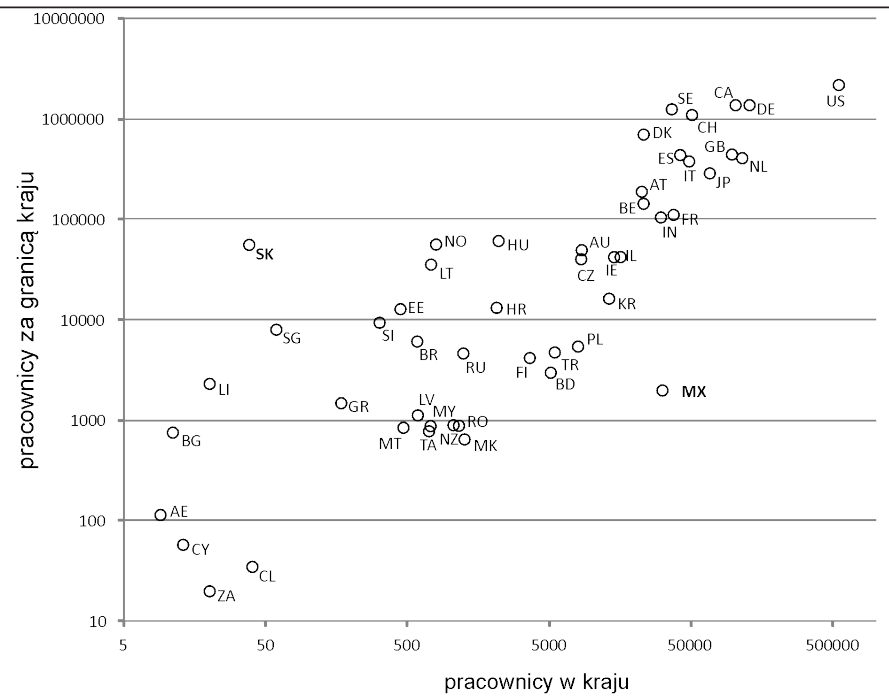

Ryc. 5. Zależność między liczbą zatrudnionych w firmach lokalnych a liczbą zatrudnionych w filiach zagranicznych w $2011 \mathrm{r}$.

Źródło: opracowanie własne na podstawie danych Biotechgate

Podobnie największa średnia liczba pracowników zatrudnionych za granicą występuje w słowackich firmach biotechnologicznych, natomiast największa średnia liczba zatrudnionych w kraju występuje w Meksyku, który z jednej strony jest potentatem biotechnologicznym (głównie w dziedzinie rolnictwa) w regionie Ameryki Środkowej, jednakże rozwija on swój przemysł biotechnologiczny głównie w oparciu o własne zasoby naukowe oraz przy wsparciu finansowym państwa (Possani Lourival 2003).

Na zróżnicowanie przestrzenne rozwoju biotechnologii wskazuje także ilość gotowych produktów trafiających na rynek oraz tych, które ciągle są doskonalone w korporacjach biotechnologicznych w różnych krajach (ryc. 7). Najwięcej produktów z tej branży powstaje w USA (19 tys.), a następnie na Litwie i w Szwajcarii. Kraje, które są na etapie intensywnych badań nad produktami to Lichtenstein, Izrael, Tajwan i Singapur. Wskaźniki te potwierdzają różnorodność krajów, w których rozwija się przemysł biotechnologiczny. Szczególną uwagę zwraca fakt dużego znaczenia krajów Europy Wschodniej, w tym głównie Litwy i Słowacji. Rozwój biotechnologii w tych krajach spowodowany jest głównie proinwestycyjną polityką państwa, korzyściami wynikającymi z przystąpienia do Unii Europejskiej, co przyczyniło się do otwarcia rynków w nowoprzyjętych krajach, duży popyt na nowe dobra konsumpcyjne oraz stosunkowo duży potencjał naukowy (Louët 2004; Amdam, Lunnan, Ramanauskas 2007; Competitiveness of the European biotechnology industry 2007; Malo, Norus 2009). Zauważa się również prawidłowość, że badania nad nowymi produktami skupiają się głównie w krajach rozwiniętych, podczas gdy produkcja skupiona jest w krajach rozwijających się, gdzie o lokalizacji produkcji decydują niskie koszty pracy, a nie potencjał intelektualny, jak np. Jemen, Filipiny, Bangladesz, Arabia Saudyjska, Azerbejdżan, Macedonia czy Pakistan (Rachwał, Wiedermann, Kilar 2009). 

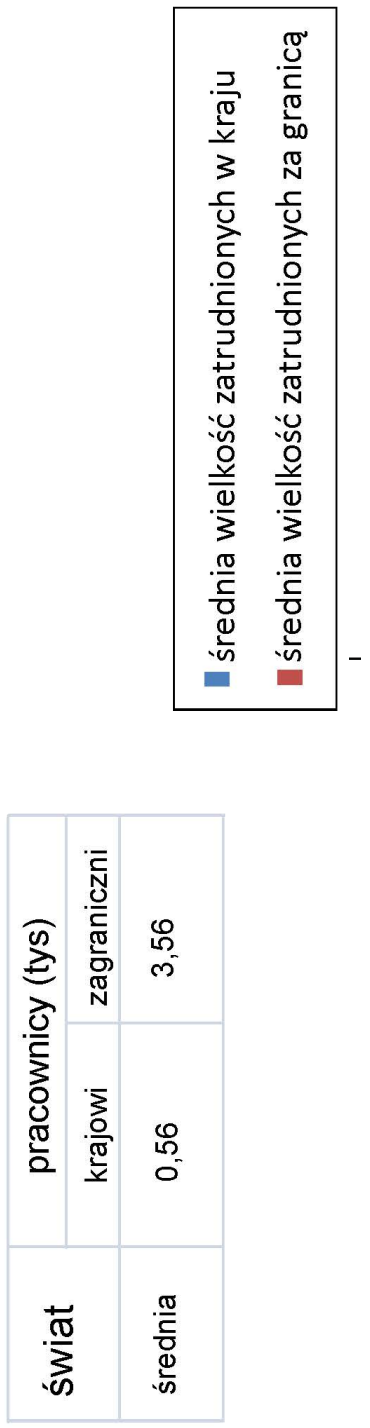

O'0 e!qunioy

IO'0 e!̣ue|s|

ZO'O $\forall d y$

$\left.\varepsilon O^{\prime} 0 \quad\right\lrcorner \mathrm{d} / \mathrm{O}^{\circ}$
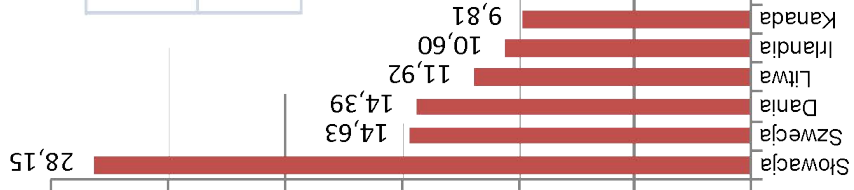

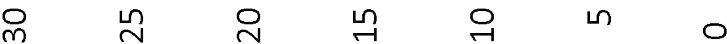

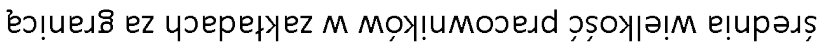

†0'0 әə!บว

tO'0 $\forall \exists Z$

$8 \tau^{\prime} 0$ - elzejew

OZ'O VUEMle

$8 \varepsilon^{\prime} 0$ -

乙†'0 [етрueju!

tt'0 upnłod вәرоY

St'0 Elununy

$8 t^{\prime} 0$ [eloun

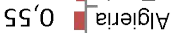

$\angle S^{\prime} 0$ e!!eEnuod

५9'0 OMOSOY

५9'0 Eḷueq| $\forall$

५9'0 eluopəoew

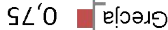

$9 \angle$ '0 elquas

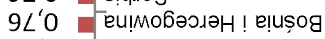

9L'0 Eụe6łng

$8 \angle$ '0 eysiod

$58^{\prime} 0-$ EHIEN

$06^{\prime} 0$ e!puejəZ EMON

$\varepsilon 6^{\prime} 0$ elsoy

OO'I Y Y

tI't eloued

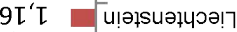

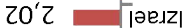

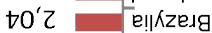

Iध'Z

$\angle S^{\prime} Z$ e!̣oㄱ

897

58' 2

- Inde6u!s

$00^{\prime} \varepsilon \quad$ zsəpe|bueg

乙द्ध $\varepsilon$

eloemouo

$\nabla \tau^{\prime} t$

$2 S^{\prime} t$

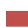

e\|leגsn $\forall$

ZL't

«

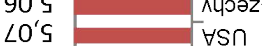

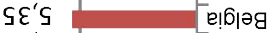

$9 \varepsilon^{\prime} \mathrm{S}$ КцоО:M

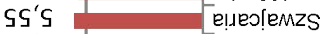

6S'S Eulsn $\forall$

08 ' $\mathrm{s}$

90 '9

$0 \varepsilon^{\prime} 9$

9

eluoder

O9'0T

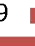

KOMอ!N

e!̣uedzs!H

epeue

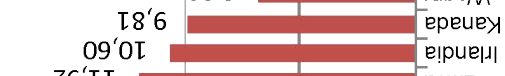

26LI EM!?

$00^{\prime} 0$ [6.nquesyn 7

IO'0 $\mathrm{d} \mathrm{d} / \mathrm{O}$

IO'0 $\forall \exists Z$

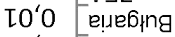

LO'0 eloemors

IO'0 elzaun $\perp$

$200^{\prime} 0 \mathrm{\forall dy}$

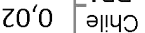

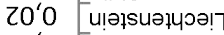

20 '0 Ем4?

Zo'0 ulexyeg

Eo'0 inde6u!s

†0'0 uelsilyed

SO'0 e!́ə丨ion

SO'0 티앜 $\exists$

SO'0 ККб̇̀

doco eloaro

90 '0 Elzndo

90 '0 elzejew

90 '0 ециəм어

80 '0 e!! Kzedg

OІ'0 емтол

II'0 ерлер[емzs

SI'0 elsoy

SI'0 entew

$\angle I^{\prime} 0$ e!puejaz emoN

8T'0 uemiel

โZ’o e!pue|u!」

$\varepsilon Z^{\prime} 0$ elununy

$t Z^{\prime} 0$ eloamzS

SC'0 eloued

$0 \varepsilon^{\prime} 0$ elzouopu

SE'0 КцоОҢМ

$\angle \mathcal{E}^{\prime} 0 \quad$ Кงแə!n

$\angle \varepsilon^{\prime} 0 \quad$ ə!рu|

$6 \varepsilon^{\prime} 0$ einea

Ot'0 upnłod eәлоу

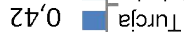

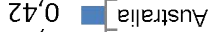

Zt'0 eloemouo

tt'0 Кцоәzว

tt'0 epeuey

St'0 eluedzs!H

$9 t^{\prime} 0$ त्रा

$9 t^{\prime} 0$ eysiod

$\angle t^{\prime} 0$ e!ulsny

$\nabla S^{\prime} 0$ |әедz|

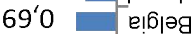

SL'O - oply ouland

†6'0 타pue|시

$86^{\prime} 0$

$0 \tau^{\prime} \mathrm{L}$

SI'I

$8 I^{\prime} \mathrm{I}$

$S Z^{\prime} \mathrm{L}$

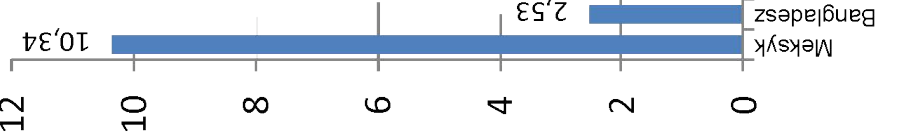

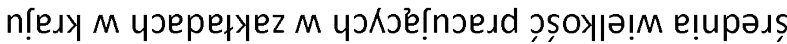




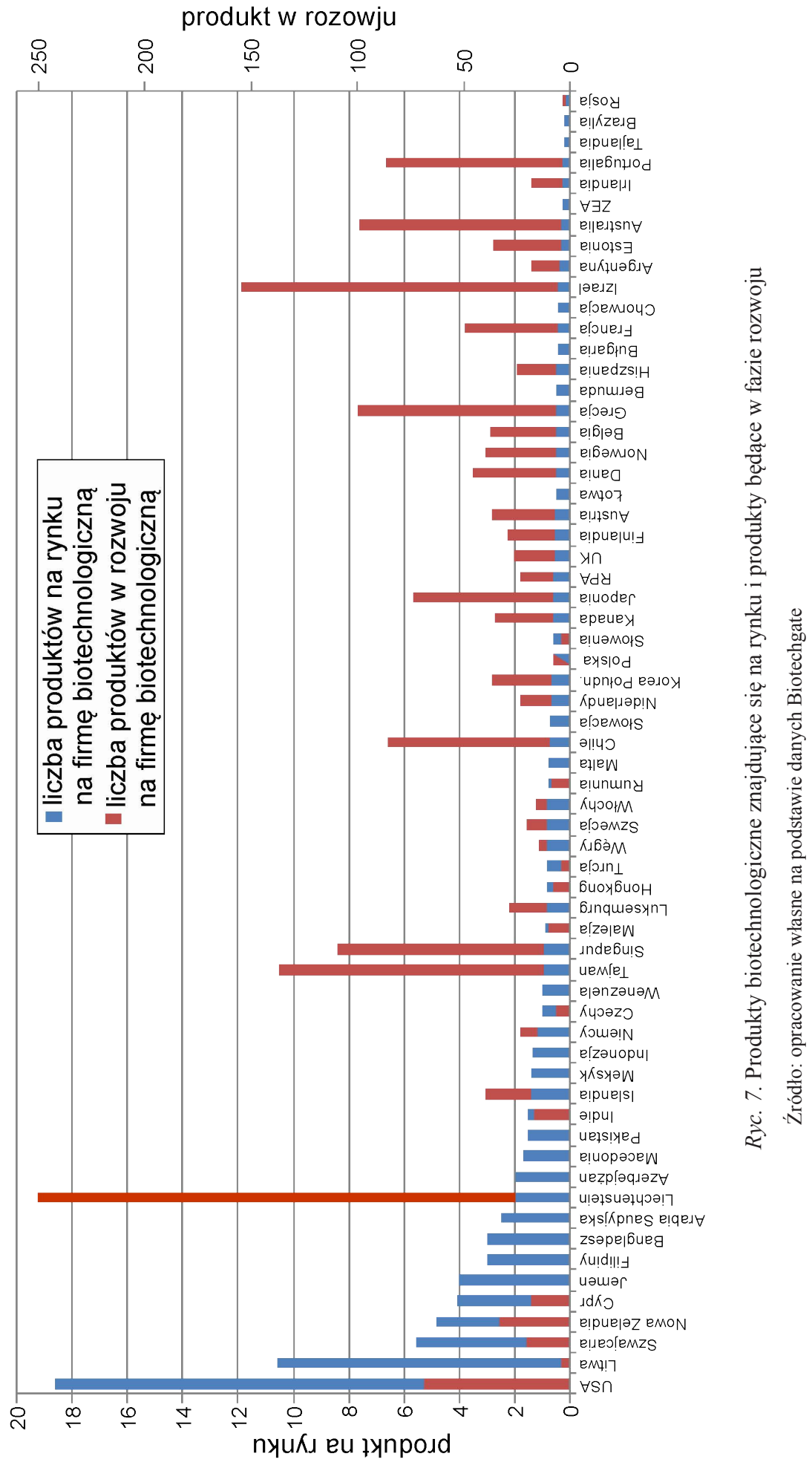


Analizując strukturę własnościową firm biotechnologicznych na świecie stwierdza się, że w większości krajów instytucje specjalizujące się w tej dziedzinie są własnością prywatną i stanowią one $82,9 \%$ ogółu korporacji (ryc. 8). W krajach rozwijających się dominują firmy prywatne, jednakże należy zwrócić uwagę na niewielką ich liczbę. Są to poza nielicznymi wyjątkami głównie kraje azjatyckie i afrykańskie. Podobnie największy udział biotechnologicznych instytucji publicznych i subsydiowanych przez państwo odnotowano w krajach rozwijających się (Kosowo, Jordania, Bangladesz, Arabia Saudyjska, Wenezuela lub Albania). Wyjątek stanowi wśród tych państw Malta, która charakteryzuje się wysokim poziomem innowacyjności gospodarki, jednakże wzrost ten jest głównie stymulowany przez instytucje państwowe, przy największym spośród wszystkich krajów UE poparciu społecznym i legislacyjnym dla postępu technologicznego, w tym biotechnologii genetycznej (Europeans and Biotechnology in 2005: Patterns and Trends). W wyniku tego Malta stanowi obecnie jeden z najszybciej rozwijających się producentów leków produkowanych w oparciu o modyfikacje genetyczne (McKenna, Galea 2004). Duży udział instytucji publicznych w rozwoju biotechnologii jest prawidłowością, charakterystyczną zarówno dla krajów rozwijających się, jak i rozwiniętych.

Biotechnologia jest działem gospodarki, w którym współpraca z instytucjami naukowymi i badawczymi jest najsilniejsza spośród innych działów innowacyjnej gospodarki. Jednakże współpraca ta ma inny wymiar w krajach rozwiniętych i rozwijających się. W krajach rozwiniętych instytucje prywatne stymulują badania prowadzone $\mathrm{w}$ instytucjach publicznych, natomiast w drugim przypadku badania finansowane są przez państwo (granty badawcze, stypendia). Wyniki tych badań wykorzystywane są przez firmy prywatne lub typu spin off (Rothaermel, Deeds 2004; Ukropcova, Sturdik 2009). System współpracy pomiędzy instytucjami B+R i podmiotami komercyjnymi jest najlepiej rozwinięty w krajach Europy i świata. Pod względem współpracy z uniwersytetami wyróżniają się Algieria i Iran (50\% ogółu firm) oraz Kolumbia, Trynidad, Meksyk czy Puerto Rico (ok. 20-30\%). Jednakże należy podkreślić, że w krajach tych liczba firm biotechnologicznych jest bardzo mała. Według liczby firm współpracujących z uczelniami na pierwsze miejsce na świecie wysuwają się USA (158 firm, czyli ok. 5\% ogółu), Kanada (121 firm) czy UK (140 firm). Firmy typu spin off to domena takich krajów jak Grecja (ponad 6\% ogółu firm) oraz Estonia, Finlandia, Włochy, Węgry czy Austria. Również w Polsce, podobnie jak w Belgii i Izraelu, odsetek firm spin off jest dość duży (ok. 0,5\%) w porównaniu z USA i Kanadą, gdzie wartość ta oscyluje ok. $0,05 \%$, dając tym krajom ostatnie miejsce w światowym rankingu według udziału firm spin off.

Wysokość przychodów z działalności w sektorze biotechnologicznym w świecie jest bardzo różna. W 2011 r. najwyższe przychody osiągały kraje wysoko rozwinięte oraz kraje z dużym potencjałem produkcyjnym (Korea Południowa, Węgry, Japonia, Indie czy RPA) (ryc. 9). Następnie wysokimi przychodami odznaczają się rozwinięte kraje Europy Zachodniej i Stany Zjednoczone Ameryki Północnej. Najniższe przychody osiągają kraje Europy Wschodniej (Litwa, Estonia, Polska, Czechy) oraz Nowa Zelandia i Finlandia, które pomimo wysokiego rozwoju technologicznego posiadają peryferyjne położenie oraz mały potencjał nabywczy. 


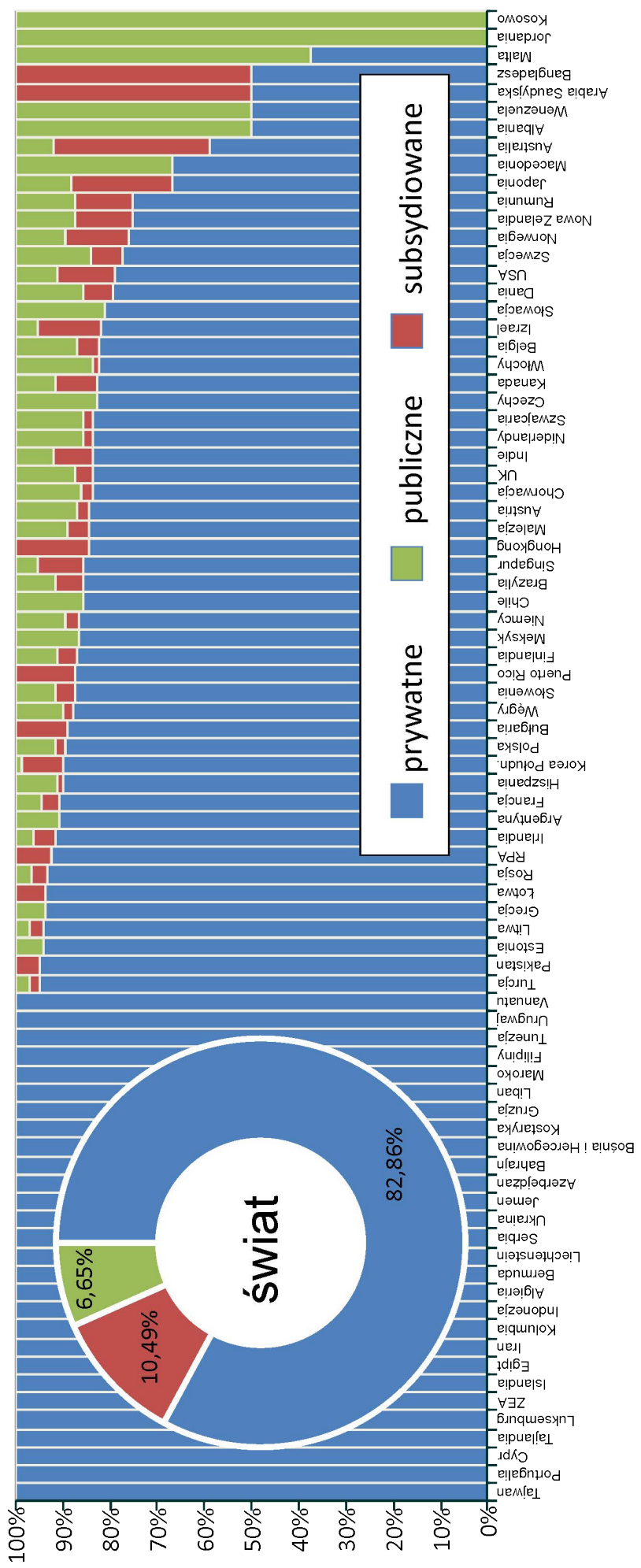




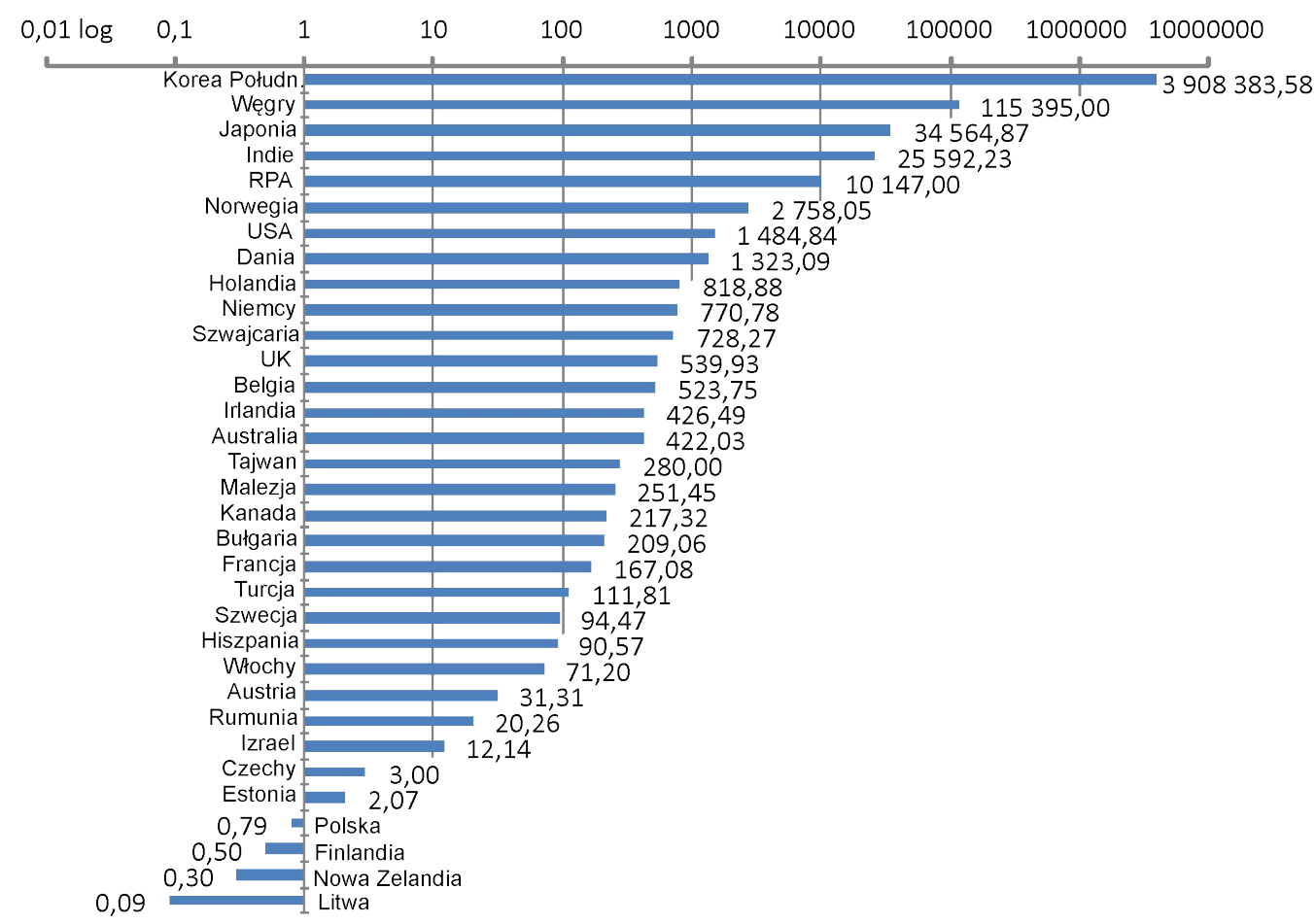

Ryc. 9. Zróżnicowanie wartości przychodu firm biotechnologicznych w $2011 \mathrm{r}$.

Źródło: opracowanie własne na podstawie danych Biotechgate

Porównując zróżnicowanie sektorów biotechnologicznych w świecie oraz Stanach Zjednoczonych i Unii Europejskiej, zauważa się, że dominującą rolę odgrywają usługi związane $\mathrm{z}$ badaniami i rozwojem, organizacje publiczne oraz dostawcy i inżynieria, zarówno na świecie, jak i w UE, gdzie ich udział łącznie wynosi ok. 55\%. (ryc. 10). Natomiast w USA największy udział stanowią najbardziej innowacyjne firmy biotechnologiczne związane $\mathrm{z}$ diagnostyką i terapią. Stosunkowo wysoki w porównaniu z Europą jest udział profesjonalnych usług i konsultingu oraz firm z zakresu technologii medycznych. Tak więc można stwierdzić, że Stany Zjednoczone, pomimo niższych wskaźników finansowych i zatrudnienia, pod względem innowacyjności przemysłu biotechnologicznego w dalszym ciągu wyprzedzają Unię Europejską.

W poszczególnych krajach zróżnicowanie sektorów firm biotechnologicznych jest bardzo duże. Największe zróżnicowanie jest w krajach wysoko rozwiniętych, w których występują wszystkie typy firm biotechnologicznych (ryc. 11). Natomiast w krajach w początkowym stadium rozwoju tego przemysłu struktura ta jest znacznie mniej zróżnicowana, gdyż przemysł biotechnologiczny reprezentowany jest zwykle przez kilka firm, które zazwyczaj nie należą do firm najbardziej innowacyjnych (biotechnologia T\&D), natomiast są to głównie firmy farmaceutyczne (produkcyjne, które bardzo często zostały przejęte przez korporacje międzynarodowe w celu łatwiejszego wejścia na krajowy rynek) i biotechnologiczne inne, czyli związane przede wszystkim z rolnictwem lub firmy usługowe. Wyraźny jest również 
w krajach rozwijających się duży udział instytucji publicznych (szpitale, uniwersytety lub stowarzyszenia i organizacje non-profit), które występują również w krajach rozwiniętych, natomiast ich rola jest odmienna, gdyż w krajach rozwijających się stanowią one zarówno zaplecze naukowe, jak i impuls do komercjalizacji badań.

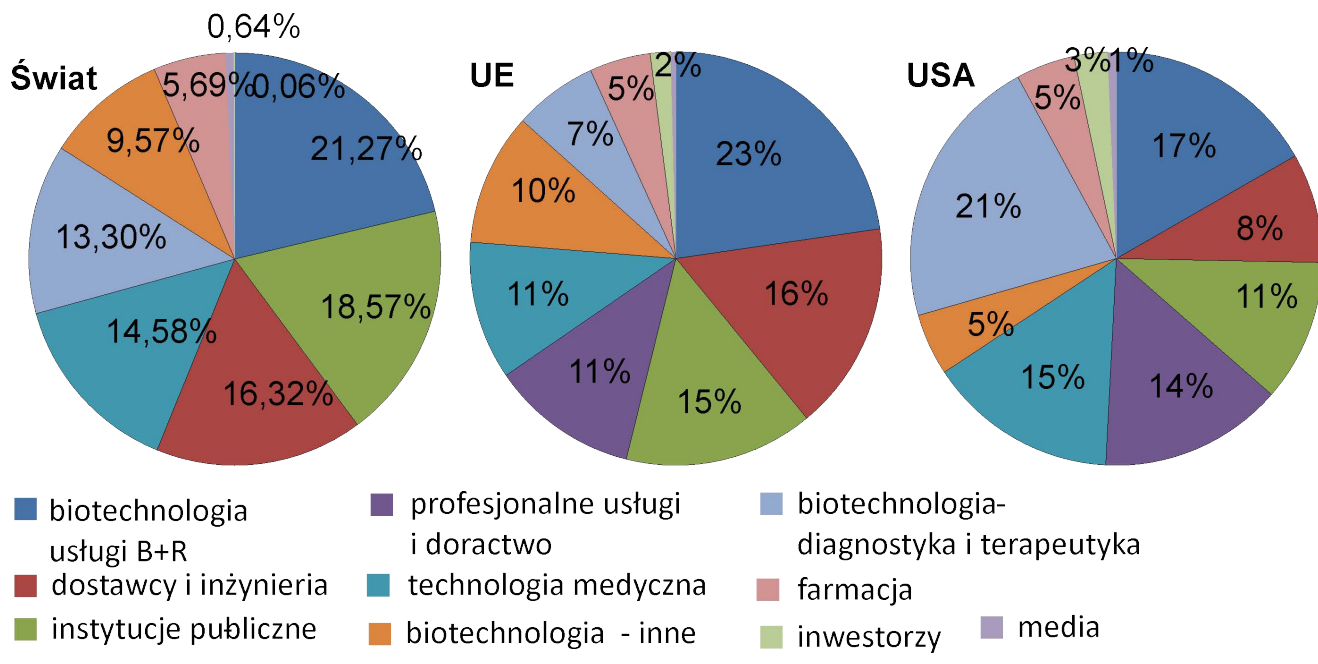

Ryc. 10. Zróżnicowanie struktury sektorów firm biotechnologicznych w 2011 r.

Źródło: opracowanie własne na podstawie danych Biotechgate

Analizując proces rozwoju firm biotechnologicznych na świecie widać wyraźnie, że najwięcej z nich powstało po 1990 roku, tj. 65,5\% ogółu firm biotechnologicznych (ryc. 12). W latach 1950-2011 obserwuje się systematyczny, prawie czternastokrotny wzrost. Można zauważyć, że boom na rozwój firm biotechnologicznych to przełom XX i XXI wieku, trwający do roku 2007, od kiedy to można zauważyć spadek liczby zakładanych nowych firm. Spadek ten był skutkiem kryzysu światowego, głównie w sferze badań podstawowych oraz spadku wielkości inwestycji (spadek inwestycji w USA i Europie w 2009 r. wyniósł ok. 46\%, choć zyski giełdowych spółek biotechnologicznych wzrosły o 12\% (Ernst \& Young’s global biotechnology report 2009). Dotyczy to głównie ryzykownych inwestycji w nowe i małe firmy, co doprowadziło do przyśpieszenia procesu koncentracji i monopolizowania przemysłu biotechnologicznego przez duże koncerny biotechnologiczne (Schimmelpfennig, Pray, Brennan 2004). Natomiast globalny przemysł biotechnologiczny okazał się być mało wrażliwy na światowy kryzys gospodarczy, na co wskazuje tylko 10\% spadek liczby firm biotechnologicznych na świecie ${ }^{2}$. Obecnie badania i największe nakłady inwestycyjne w branży biotechnologicznej skierowane są głównie na przemysł farmaceutyczny (przede wszystkim onkologia, diabetyka i choroby autoimmunologiczne) (Aggarwal 2010). Dodatkowo do spadku atrakcyjności

${ }^{2}$ http://www.businesswire.com/news/home/20100930006565/en/Number-Biotechnology-Companies-Decreased-10-Crisis 


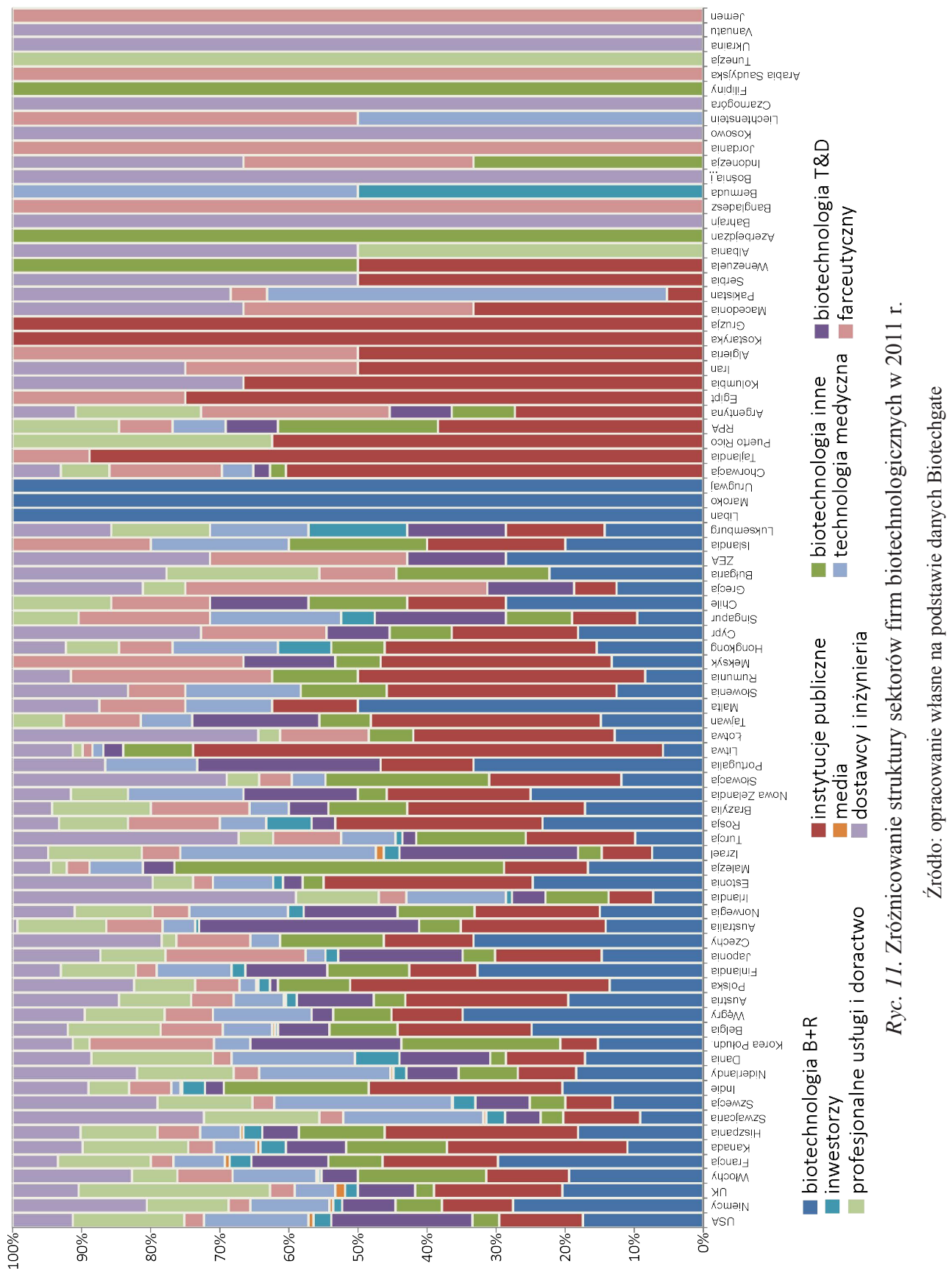


prowadzenia badań biotechnologicznych z zakresu DNA i modyfikacji genów, przyczyniły się restrykcyjne zapisy w legislacji (w tym prawo patentowe) wielu krajów oraz zmiana postaw społecznych względem produktów transgenicznych (neoluddytyzm).

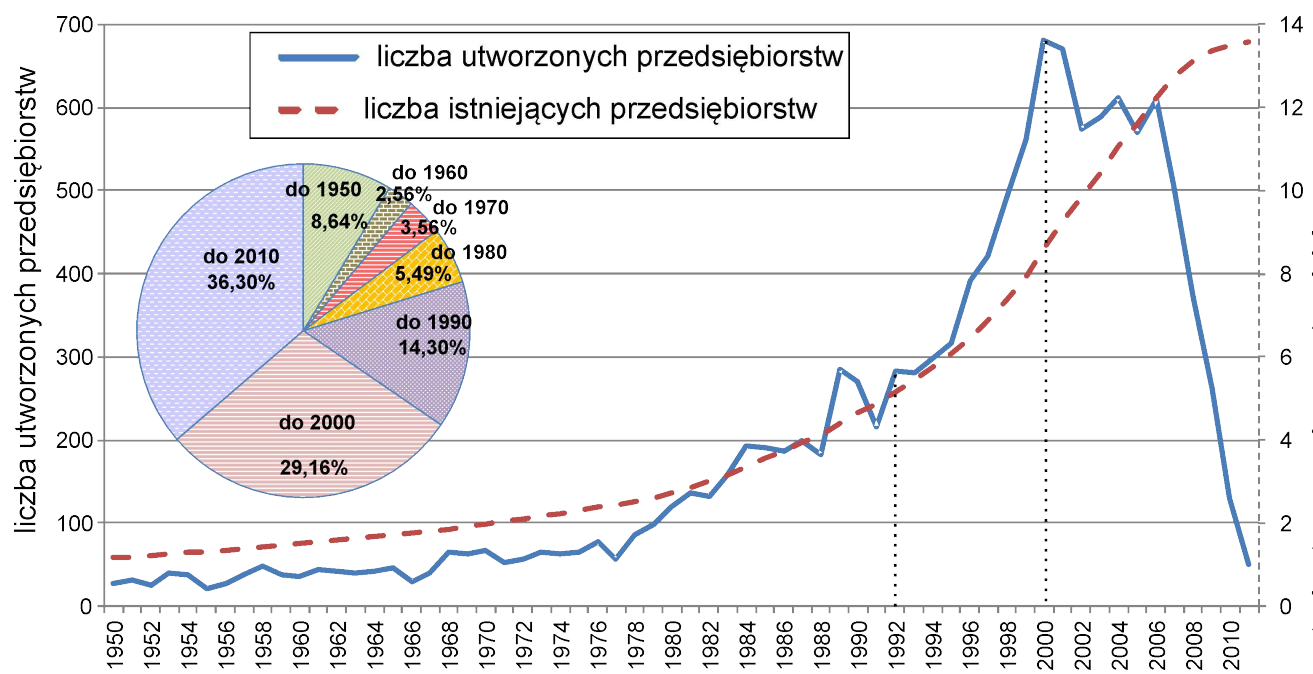

Ryc. 12. Zmiany liczby zakładanych firm biotechnologicznych w latach 1950-2011

Źródło: opracowanie własne na podstawie danych Biotechgate

W badanych latach warunki dla rozwoju firm biotechnologicznych w poszczególnych państwach były zróżnicowane i w ostatnim dziesięcioleciu ich rozwój następował głównie w państwach, które nie percypowały w światowym rynku biotechnologicznym (ryc. 13). Największy udział najstarszych firm biotechnologicznych obserwujemy w Macedonii, Wenezueli, Chile czy Kolumbii. Jest to wynikiem z jednej strony małej ilości instytucji biotechnologicznych, jak i dużego udziału uczelni i instytucji państwowych w tych krajach, które powstały często w pierwszej połowie XX w., a obecnie dostosowały swój profil do potrzeb rozwijającego się rynku biotechnologicznego. Z drugiej strony mamy kraje takie jak Serbia, Maroko, Liechtenstein, Liban, Bermudy, Urugwaj, Jemen lub Ukraina, w których dominują firmy założone tylko w ostatnich 20 latach. Są to kraje, które dopiero niedawno rozpoczęły rozwój innowacyjnych gałęzi gospodarki i w wielu przypadkach odbywa się to przez proces delokalizacji produkcji wielkich korporacji z krajów rozwiniętych. Polska w tym zestawieniu znajduje się w czołówce, wśród państw, gdzie dominują firmy biotechnologiczne mające swój początek w drugiej połowie XX w. (20\% firm to założone do 1950 r.) i tylko ok. 50\% firm założonych jest po 1990 roku. Tymczasem w krajach rozwiniętych (np. USA, Niemcy, Francja) udział firm założonych po 1990 roku, a więc w czasie największego boomu biotechnologicznego, stanowi przeszło 70\% ogólnej liczby firm. 


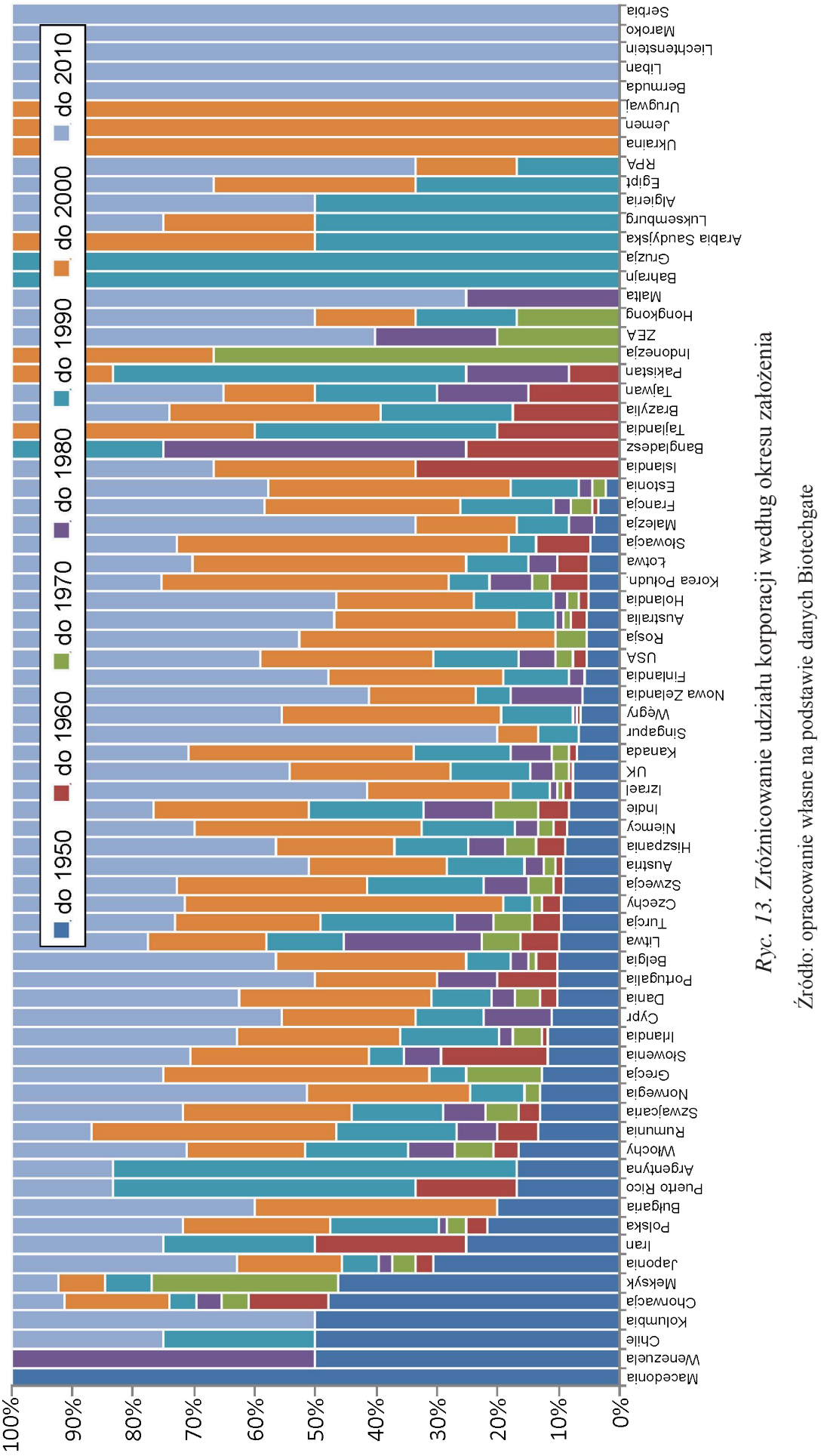


PROCES KSZTAŁTOWANIA FIRM BIOTECHNOLOGICZNYCH ORAZ SZKOLNICTWA wyŻsZego i dZialalność B+R w Zakresie biotechnologi w Polsce

Kolejnym etapem podjętych prac badawczych było określenie procesów kształtowania, zróżnicowania potencjału i struktury przemysłu biotechnologicznego w Polsce, który w porównaniu z krajami wysokorozwiniętymi w Polsce znajduje się w początkowym stadium rozwoju.

W latach 1950-2010 liczba zarejestrowanych w bazie Biotechgate firm biotechnologicznych w Polsce zwiększyła się z 7 do 140 (ryc. 14). W okresie tym wyraźnie zmieniały się warunki dla rozwoju tego przemysłu. Najwyższa dynamika wzrostu nowo zakładanych firm zaznacza się w latach zmian systemu gospodarowania w Polsce. Firmy powstałe po $1990 \mathrm{r}$. stanowią $52 \%$ ogólnej ich liczby i odpowiada to światowej strukturze firm. W ostatnim dwudziestoleciu firmy biotechnologiczne pojawiały się zarówno w dużych miastach (Warszawa, Łódź, Kraków, Gdańsk, Wrocław), z którymi przemysł ten był związany już w latach wcześniejszych (głównie był to przemysł farmaceutyczny), jak również pojawiały się nowe ośrodki wzrostu, skupione wokół istniejących centrów biotechnologicznych. Największa liczba takich firm zlokalizowana jest w województwach: mazowieckim, pomorskim oraz śląskim i małopolskim.

Dominującą rolę pod względem liczby firm biotechnologicznych odgrywają dwa miasta: Warszawa i Kraków, które skupiają po ok 60 przedsiębiorstw biotechnologicznych. Zaznacza się też różny stopień rozproszenia tych firm w poszczególnych województwach oraz pod względem zróżnicowania ich typów (ryc. 15).

W Polsce firmy przemysłu biotechnologicznego w $90 \%$ są własnością prywatną i reprezentują różne typy instytucjonalne. Największe zróżnicowanie tej struktury występuje w największych miastach będących głównymi ośrodkami szkolnictwa wyższego w kraju, w których zlokalizowane są uniwersytety i instytuty badawcze (ryc. 16). Pierwsze pozycje wśród polskich firm biotechnologicznych zajmują przedsiębiorstwa $\mathrm{z}$ baraży farmaceutycznej i spożywczej, następne w kolejności są zakłady związane z rolnictwem, przemysłem kosmetycznym oraz produkcją urządzeń i usługami medycznymi. Bardzo mało jest natomiast podmiotów komercyjnych z branży badawczej i zaawansowanej techniki biotechnologicznej. Najwięcej instytutów badawczych zlokalizowanych jest w Warszawie oraz w sąsiednich miejscowościach (Otwock, Radom).

Dużym potencjałem naukowym charakteryzuje się również ośrodek wrocławski (klaster Nutribiomed i Wrocławskie Centrum Badań EIT+) i ośrodek łódzki (Łódzki Klub Firm Biotechnologicznych). Natomiast w sferze rozwoju biotechnologii medycznej duże znaczenie ma Kraków (klaster LifeScience). Zwraca również uwagę Pomorski Klaster BioEcoChemiczny i Pomorski Klaster Biotechnologii, Farmacji i Kosmetyków oraz Śląska Bio-Farma, Centrum Biotechnologii, Bioinżynierii i Bioinformatyki. Pomimo krytyki stosowania $w$ wielu przypadkach terminu klastra ${ }^{3}$ (często jest to wymóg nomenklatury), należy zaznaczyć, że współcześnie zauważalny jest proces tworzenia się w Polsce terytorialnych

\footnotetext{
3 Szerzej na temat klastrów innowacyjnych pisali m.in. Gierańczyk 2008, Micek 2008b, Bal-Woźniak 2009.
} 


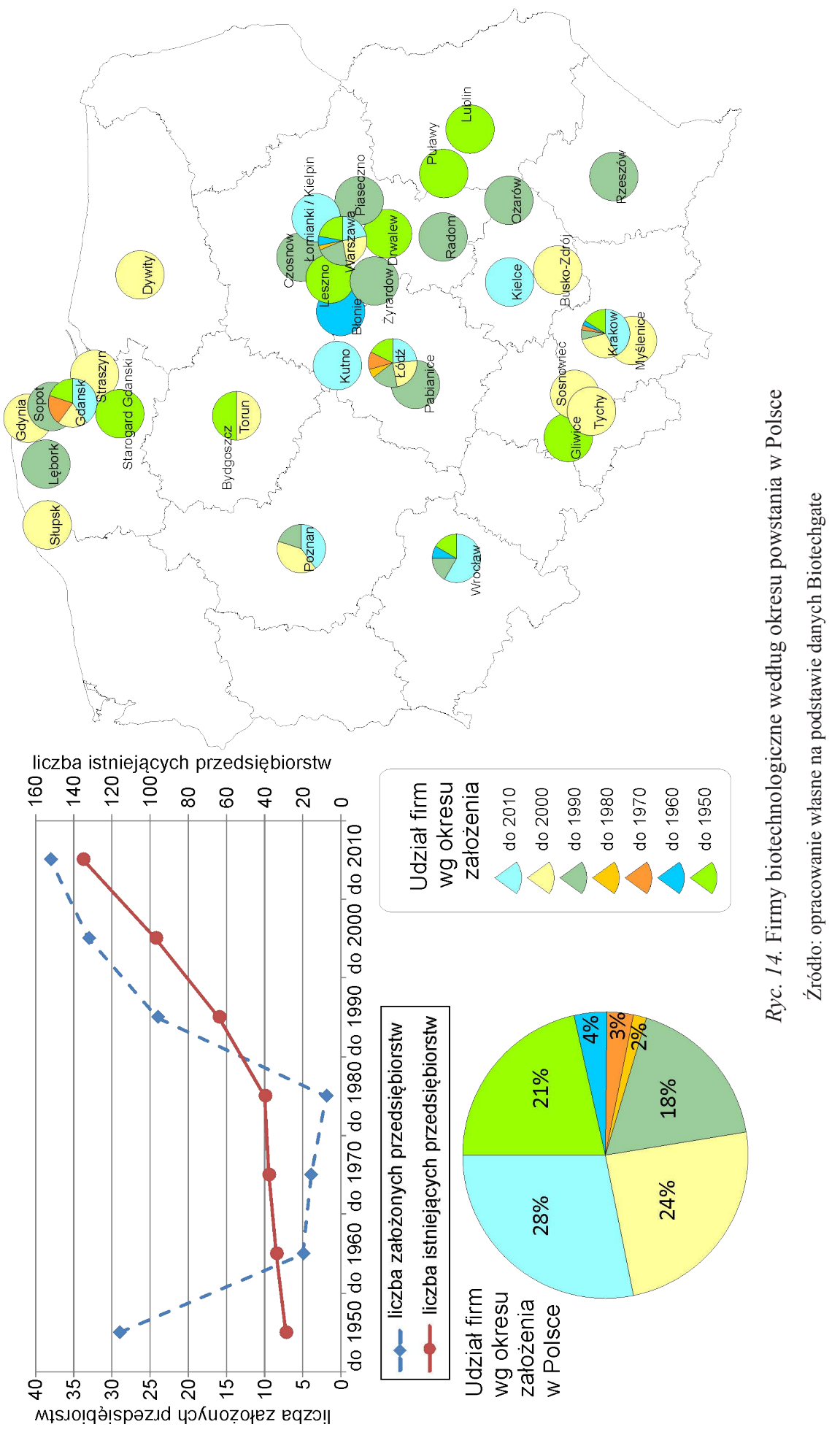


sieci powiązań i skupień związanych z rozwojem biotechnologii. Z doświadczeń wynika, że w przypadku rozwoju nowoczesnej gospodarki (w tym biotechnologii) sieci takie są niezbędne do generowania innowacji (Gertler, Levitte 2005; Cooke 2002). Szczególnie ważna w tym procesie jest współpraca na poziomie badawczym i produkcyjnym przez powiązania nauki i gospodarki, co w polskich realiach jest w początkowym etapie rozwoju.

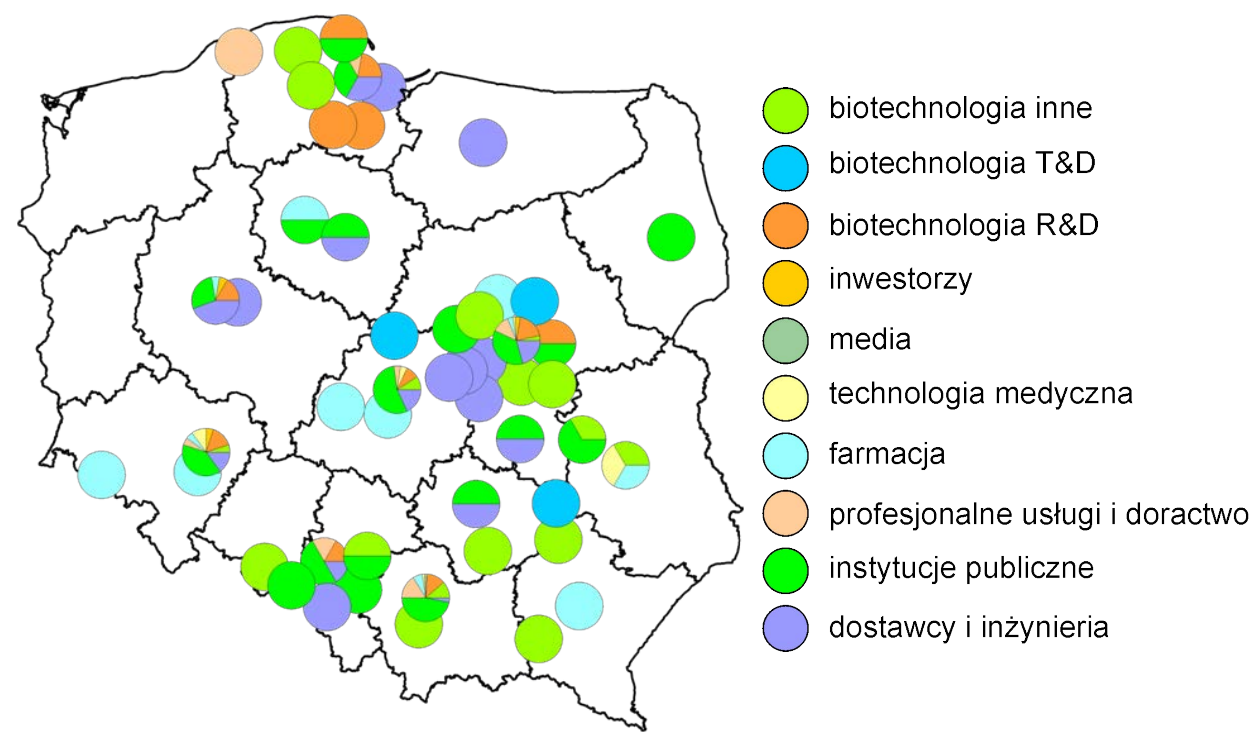

Ryc. 15. Zróżnicowanie liczby i typów korporacji biotechnologicznych w Polsce

Źródło: opracowanie własne na podstawie danych Biotechgate

Analogicznie, największa ilość produktów biotechnologicznych wytwarzana jest przez firmy zlokalizowane w Krakowie, Warszawie i Wrocławiu (ryc. 17A). W większości są to produkty dostępne na rynku, a tylko niewielki ich udział jest w fazie rozwoju i w tym przypadku dominuje w Polsce wyraźnie ośrodek krakowski.

Jednakże w analizie rozmieszczenia podmiotów zarejestrowanych w PKD w klasie: badania naukowe i prace rozwojowe w dziedzinie biotechnologii można zauważyć wyraźną dominację Warszawy oraz Wrocławia i Łodzi (ryc. 17B). Pod względem ilości podmiotów biotechnologicznych wyróżnia się także Poznań wraz z sąsiadującymi miastami. Wśród zarejestrowanych podmiotów dominują głównie mikroprzedsiębiorstwa i są to głównie firmy powstałe w ostatnich dziesięciu latach. Rozmieszczenie przedsiębiorstw silnie koreluje z lokalizacją biotechnologicznych ośrodków naukowych, co może potwierdzać, że są to w dużej mierze przedsiębiorstwa typu spin off.

$\mathrm{W}$ dalszych badaniach zmierzano do określenia roli szkolnictwa wyższego w rozwoju przemysłu biotechnologicznego w Polsce.

Rozwój kształcenia w zakresie biotechnologii następuje w 21 uczelniach, w których W roku akademickim 2012/2013 na ten kierunek przyjęto 13,0 tys. studentów, co klasyfikowało go na 17 miejscu wśród najbardziej popularnych kierunków w Polsce. Kształcenie 

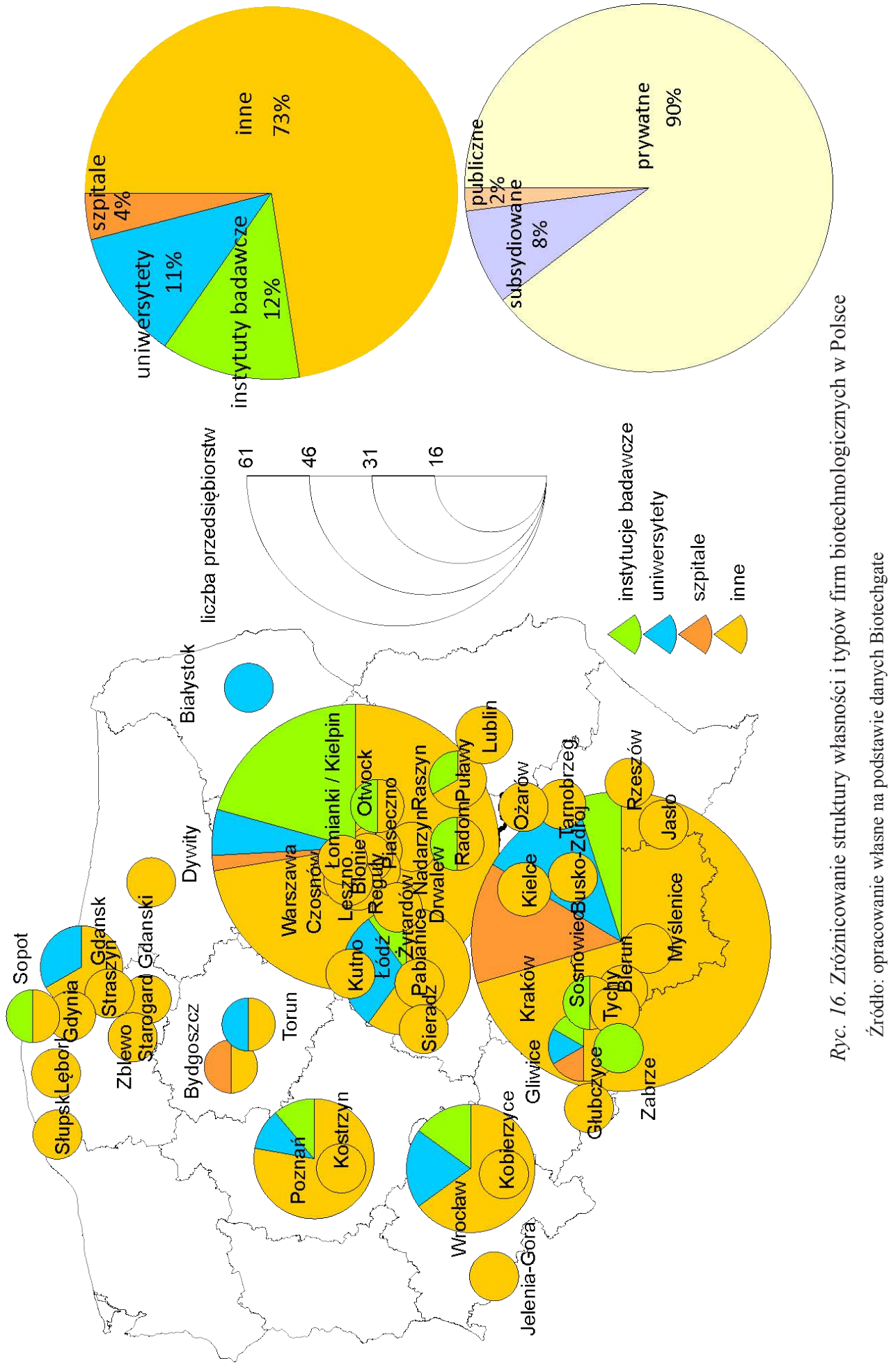


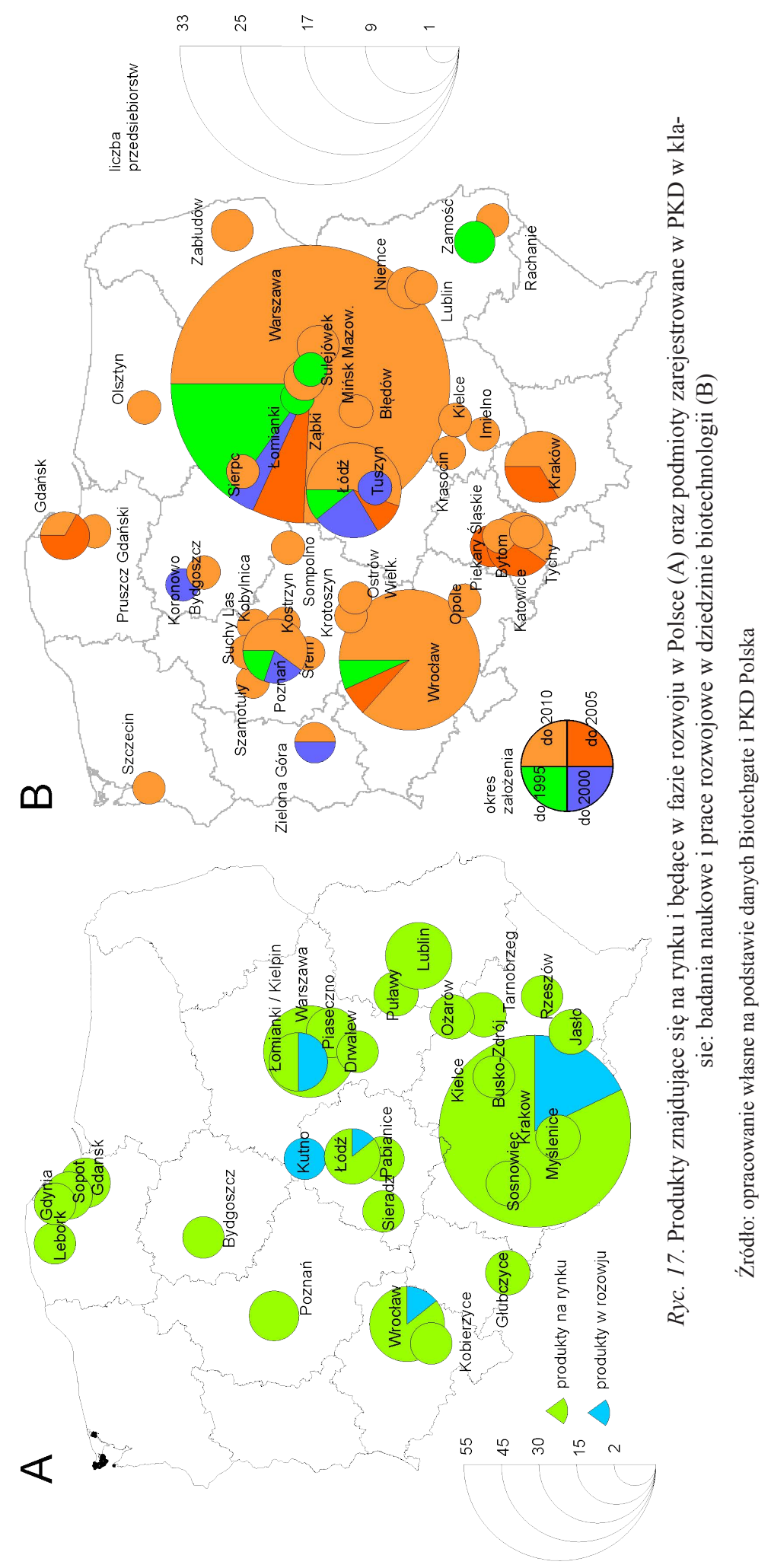


w zakresie biotechnologii odbywa się zarówno w głównych ośrodkach akademickich (Kraków, Katowice, Lublin, Poznań, Toruń, Warszawa, Wrocław), jak i w mniejszych ośrodkach (Białystok, Bydgoszcz, Częstochowa, Gdańsk, Gliwice, Kielce, Olsztyn, Opole, Rzeszów, Szczecin, Zielona Góra). Rozmieszczenie ośrodków uniwersyteckich, jak już wspomniano, pokrywa się z lokalizacją ośrodków przemysłu biotechnologicznego. Potwierdza to silny związek pomiędzy instytucjami naukowymi a rozwojem biotechnologii.

W strukturze działalności $\mathrm{B}+\mathrm{R}$ w dziedzinie biotechnologii zbliżony jest udział jednostek sektora rządowego $(34,9 \%)$, szkolnictwa wyższego $(33,6 \%)$ i sektora przedsiębiorstw (31,5\%). Świadczy to o klastrowym charakterze przemysłu biotechnologicznego, łączącego zarówno instytucje publiczne, naukowe, jak i komercyjne. Natomiast w strukturze zatrudnionych w działalności B+R w zakresie biotechnologii aż 54,8\% stanowią zatrudnieni w szkolnictwie wyższym, 39,8\% w sektorze rządowym, a zaledwie 5,4\% w przedsiębiorstwach. Potwierdza to wcześniejszą tezę, że w Polsce, tak jak i w innych krajach rozwijających się, innowacyjność w biotechnologii kreowana jest głównie przez podmioty publiczne, które w wyniku procesów komercjalizacji prowadzonych badań są wykorzystywane w produkcji, natomiast nie następuje stymulacja badań przez sektor prywatny. $\mathrm{O}$ znaczeniu sektora nauki w przemyśle biotechnologicznym może świadczyć struktura zatrudnienia w działalności badawczej. Wśród zatrudnionych w sektorze $\mathrm{B}+\mathrm{R}$ w dziedzinie biotechnologii, najwyższy udział stanowią osoby ze stopniem doktora - niemal 37,8\%, co jest jednym z najwyższych udziałów wśród działów innowacyjnych gospodarki. Następnymi w kolejności są pracownicy z wykształceniem wyższym - 33,0\%. Również średnie nakłady na 1 pracownika naukowo-badawczego w dziedzinie biotechnologii były o 10 tys. wyższe niż średnie nakłady na działalność B+R w Polsce, wynoszące 103,2 tys. zł. Wskaźniki te świadczą o istnieniu silnych powiązań pomiędzy ośrodkami naukowymi (również poprzez finansowanie badań przez instytucje państwowe i publiczne) z przemysłem biotechnologicznym.

\section{ZAKOŃCZENIE}

Podsumowując, zróżnicowanie przestrzenne i strukturalne przemysłu biotechnologicznego na świecie jest bardzo duże. Największe znaczenie w jego rozwoju mają rozwinięte gospodarczo kraje, takie jak: USA, a następnie kraje europejskie, głównie Niemcy, Wielka Brytania, Szwajcaria, Włochy, Szwecja oraz pozaeuropejskie: Kanada, Indie, Korea Południowa, Japonia. Współcześnie pojawiają się nowe centra przyspieszonego rozwoju przemysłu biotechnologicznego, m.in. na Litwie, w Hiszpanii, w Turcji, na Słowacji. Innowacje powstają $\mathrm{w}$ pierwszej kolejności $\mathrm{w}$ macierzystych krajach korporacji, a dopiero wraz z upływem czasu produkcja jest przenoszona do innych krajów oraz na nowe rynki zbytu. Problemy związane z modelem transformacji i selektywnym napływem kapitału zagranicznego w mniej zaawansowaną produkcję są obecnie coraz silniej akcentowane (Raport „Polska 2050” 2011). W Polsce przemysł ten w dużym stopniu rozwija się w oparciu o potencjał ośrodków naukowych i w obszarach metropolitalnych. Możliwości rozwoju branży zależą w dużym stopniu od dostępności wysoko wykwalifikowanej kadry, 
rozwiniętego technologicznie zaplecza badawczo-rozwojowego, polityki proinnowacyjnej państwa, współpracy międzynarodowej i dostępności do kapitału.

\section{Literatura / References}

Aggarwal, S. (2010). What's fueling the biotech engine 2009-2010. Nature Biotechnology, 28(11), $1165-1171$.

Amdam, R.P., Lunnan, R., Ramanauskas, G. (2007). FDI and the Transformation from Industry to Service Society in Emerging Economies: A Lithuanian-Nordic Perspective. Engineering Economics, 1(51), 22-28.

Bal-Woźniak, T. (2009). Infrastruktura systemu innowacyjnego jako czynnik transformacji struktur przemysłowych. Prace Komisji Geografii Przemystu Polskiego Towarzystwa Geograficznego, $12,45-58$.

Baum J.A.C., Silverman B.S. (2004). Picking winners or building them? Alliance, intellectual, and human capital as selection criteria in venture financing and performance of biotechnology startups. Journal of Business Venturing, 19, 411-436.

Competitiveness of the European biotechnology industry 2007, European Commission, Enterprise and Industry DG, Working document, 26.

Cooke, P. (2002). Biotechnology Clusters as Regional, Sectoral Innovation Systems. International Regional Science Review, 25(1), 8-37.

Dobos, E., Karaali, A. (2003). Capacity Building in Agricultural Biotechnology in Turkey. Food Reviews International, 19(4), 437-445.

Dorocki, S. (2011). Inwestycje zagraniczne we Francji w dobie globalizacji. Przedsiębiorczość Edukacja, 7, 24-41.

Europeans and Biotechnology in 2005: Patterns and Trends (2006). Final report on Eurobarometer 64.3, 87. Pozyskano z: http://www.ask-force.org/web/Eurobaro/Eurobaro-2005-ebs_244b_en.pdf.

Falk, M.C., Chassy, B.M., Harlander, S.K., Hoban, T.J., McGloughlin, M.N., Akhlaghi, A.R. (2002). Food Biotechnology: Benefits and Concerns. The Journal of Nutrition, 132(6), 1384-1390.

Gertler, M.S., Levitte, Y.M. (2005). Local Nodes in Global Networks: The Geography of Knowledge Flows in Biotechnology Innovation. Cornell University, School of Industrial and Labor Relations. Pozyskano z: http://digitalcommons.ilr.cornell.edu/articles/122.

Gierańczyk, W. (2008). Badanie struktur przemysłowych w Polsce w dobie globalizacji ze szczególnym uwzględnieniem struktury przestrzennej. Prace Komisji Geografii Przemystu Polskiego Towarzystwa Geograficznego, 11, 26-39.

Grebel, T., Krafft, J., Saviotti, P.P. (2006). On the life cycle of knowledge intensive sectors. Revue OFCE, 97(5), 63-85.

Kenney, M., Buttel, F. (1985). Biotechnology: Prospects and Dilemmas for Third World Development. Development and Change, 16(1), 61-91.

Kilvits, K., Purju, A. (2007). Delocalization of Industries and the Role of Governing Institutions with Evidences from Estonia. The 19th European Association for Evolutionary Political Economy (EAEPE) Book of Abstracts "Economic Growth, Development and Institutions - Lessons for Policy and the Need for an Evolutionary Framework of Analysis", University of Porto, 55.

Louët, S. (2004). EU enlargement brings biotech opportunities. Nature Biotechnology, 22, 493-494. 
Lux, G. (2009). The re-emerging role of industry in Central European economies. W: B. Baranyi, I. Fodor (red.), The role of environmental industry in the regional reindustrialisation in Hungary. Debrecen-Pécss: Hungarian Academy of Sciences, Centre for Regional Studies, 19-35.

Malo, S., Norus, J. (2009). Growth dynamics of dedicated biotechnology firms in transition economies. Evidence from the Baltic countries and Poland. Entrepreneurship and Regional Development, 21(5-6), 481-502, DOI: 10.1080/08985620802332749.

McKenna, A., Galea, M. (2004). The Manufacture of Generic Pharmaceuticals in Malta: A First Step. The Business Journal for the Generic Medicines Sector, 2(1), 63-70, doi: 10.1057/palgrave.jgm. 4940053.

Micek, G. (2008a). Exploring the role of sticky places in attracting the software industry to Poland. Geographia Polonica, 81(2), 43-60.

Micek, G. (2008b). Grona przedsiębiorczości jako przedmiot analizy oraz instrument rozwoju lokalnego i regionalnego w warunkach polskich. Przeglad Geograficzny, 80(4), 541-558.

Orsenigo, L. (2006). Clusters and clustering in biotechnology: stylised facts, issues and theories. W: P. Braunerhjelm, M.P. Feldman (red.), Cluster Genesis. Oxford, UK: Oxford University Press, 195-218.

Possani Lourival, D. (2003). The past, present, and future of biotechnology in Mexico. Nature Biotechnology, 21, 582-583. doi:10.1038/nbt0503-582.

Pugatch, M.P., Torstensson, D., Chu, R. (2012). Taking Stock: How Global Biotechnology Benefits from Intellectual Property Rights, Pugatch Consilium, Commissioned by the Biotechnology Industry Organization. Pozyskano z: http://www.bio.org/../Pugatch\%20Consilium\%20-\%20 Taking\%20Stock\%20Final \%20Report\%20(2).pdf.

Rachwał, T., Wiedermann, K., Kilar, W. (2009). Rola przemysłu w gospodarce układów regionalnych Unii Europejskiej. Prace Komisji Geografii Przemystu Polskiego Towarzystwa Geograficznego, $14,31-42$.

Raport „Polska 2050” (2011). Komitet Prognoz „Polska 2000 Plus”. Polska Akademia Nauk.

Rothaermel, F.T., Deeds, D.L. (2004). Exploration and exploitation alliances in biotechnology: a system of new product development. Strategic Management Journal, 25, 201-221.

Schimmelpfennig, D.E., Pray, C.E., Brennan, M.F. (2004). The impact of seed industry concentration on innovation: a study of US biotech market leaders. Agricultural Economics, 30, 157-167.

Ukropcova, D., Sturdik, E. (2009). Biotechnology commercialisation in Europe. Nova Biotechnologica, 9(3), 255-264.

Weijian, S., Jaeyong, S. (1997). Foreign Direct Investment and the Sourcing of Technological Advantage: Evidence from the Biotechnology Industry. Journal of International Business Studies, 28(2), 267-284.

Zioło, Z. (2006). Zróżnicowanie światowej przestrzeni przemysłowej w świetle koncentracji siedzib zarządów wiodących korporacji. Prace Komisji Geografii Przemystu Polskiego Towarzystwa Geograficznego, 8, 9-26.

Zioło, Z. (2008). Procesy transformacji przemysłowych układów przestrzennych na tle zmieniającego się otoczenia. Prace Komisji Geografii Przemystu Polskiego Towarzystwa Geograficznego, 10, $11-22$. 
Sławomir Dorocki, dr, Uniwersytet Pedagogiczny w Krakowie, Instytut Geografii, Zakład Przedsiębiorczości i Gospodarki Przestrzennej.

Absolwent studiów z zakresu geografii społeczno-ekonomicznej Uniwersytetu Pedagogicznego w Krakowie, doktor nauk humanistycznych w dyscyplinie historia (Instytut Europeistyki - Uniwersytet Jagielloński). Adiunkt w Instytucie Geografii Uniwersytetu Pedagogicznego w Krakowie. Jego zainteresowania badawcze skupiają się wokół problematyki regionów i procesów regionalizacji społeczno-gospodarczej, ze szczególnym uwzględnieniem zróżnicowania przestrzeni europejskiej oraz procesów integracji europejskiej i uwarunkowań historycznych.

Sławomir Dorocki, Ph.D., Pedagogical University of Cracow, Institute of Geography, Department of Entrepreneurship and spatial Management.

Graduated from Pedagogical University in Cracow MA degree in geography, Ph.D. in history (Institute of European Studies of the Jagiellonian University). Senior Lecturer at Pedagogical University of Cracow, Institute of Geography. His research interests focus on regional problems and processes of socio-economic regionalization, with particular emphasis on the diversity of Europe, processes of European integration and historical conditions.

Marta Boguś, mgr, Uniwersytet Pedagogiczny w Krakowie, Instytut Geografii, Zakład Przedsiębiorczości i Gospodarki Przestrzennej.

Magister geografii ze specjalnością geografia z przedsiębiorczością i gospodarką przestrzenną w Instytucie Geografii Uniwersytetu Pedagogicznego w Krakowie. Jej zainteresowania badawcze skupiają się wokół problematyki gospodarki opartej na wiedzy oraz kształtowania się korporacji międzynarodowych na tle zachodzących procesów globalizacji i integracji europejskiej.

Marta Boguś, M.Sc., Pedagogical University of Cracow, Institute of Geography, Department of Entrepreneurship and spatial Management.

Master in Geography, with specialization in Geography, Entrepreneurship and Spatial Management at Pedagogical University of Cracow. Her research interests focus on the knowledge-based economy and the creation of multinational corporations against the process of globalization and European integration.

Monika Borowiec, dr, Uniwersytet Pedagogiczny w Krakowie, Instytut Geografii, Zakład Przedsiębiorczości i Gospodarki Przestrzennej.

Doktor nauk o Ziemi w zakresie geografii, adiunkt w Instytucie Geografii Uniwersytetu Pedagogicznego w Krakowie. Jej zainteresowania badawcze koncentrują się wokół problematyki gospodarki opartej na wiedzy, roli szkolnictwa wyższego i ośrodków naukowych w procesie kształtowania społeczeństwa informacyjnego, procesów transformacji społeczno-gospodarczej, ze szczególnym uwzględnieniem procesów globalizacji i integracji europejskiej, a także problematyki przedsiębiorczości.

Monika Borowiec, Ph.D., Pedagogical University of Cracow, Institute of Geography, Department of Entrepreneurship and spatial Management.

$\mathrm{PhD}$ in Earth Sciences in the field of Geography, Senior Lecturer at Pedagogical University of Cracow, Institute of Geography. Her interests focus on a knowledge-based economy, the role of higher education and academic centers in the process of socio-economic transformation, processes of globalization and European integration.

adres/address: Uniwersytet Pedagogiczny w Krakowie

Instytut Geografii

Zakład Przedsiębiorczości i Gospodarki Przestrzennej

ul. Podchorążych 2, 30-084 Kraków, Polska

e-mail: sdorocki@up.krakow.pl (Sławomir Dorocki),

mbogus@up.krakow.pl (Marta Boguś),

borowiec@up.krakow.pl (Monika Borowiec) 